\title{
ARE TROPICAL PLANTS BETTER DEFENDED? PALATABILITY AND DEFENSES OF TEMPERATE VS. TROPICAL SEAWEEDS ${ }^{1}$
}

\author{
ROBIN C. BOLSER AND MARK E. HAY ${ }^{2}$ \\ University of North Carolina at Chapel Hill, Institute of Marine Science, 3431 Arendell Street, \\ Morehead City, North Carolina 28557 USA
}

\begin{abstract}
Investigators working in both terrestrial and marine systems hypothesize that prey defenses are better developed in tropical than in temperate habitats because tropical consumers are more active and diverse. To investigate the hypothesis that chemical defenses are more potent in tropical than in temperate seaweeds, we conducted 38 feeding assays involving seven genera of algae. We offered tropical and temperate sea urchins the choice of a temperate alga from North Carolina or a closely related tropical alga from the Bahamas. Plants were freeze-dried, ground to a fine powder, embedded in agar, and presented in congeneric pairs (North Carolina species vs. Bahamian species), or same-species pairs, to the temperate urchin Arbacia punctulata and the tropical urchin Lytechinus variegatus. For the genera we tested (the red alga Amphiroa, the green alga Udotea, and the brown algae Dictyopteris, Dictyota, Lobophora, Padina, and Sargassum), we documented a general pattern in which the mean amount of North Carolina seaweeds eaten was approximately twice that of their Bahamian congeners. Dictyota was an exception to the overall pattern, in that mean consumption of temperate and tropical species was equivalent. In addition to showing a latitudinal difference in seaweed palatability, we found that some species exhibited significant, between-population variation in herbivore resistance on a local scale. The most notable example was Dictyota menstrualis from North Carolina. When collected from a shallow inshore site, this species was significantly more palatable than tropical species of Dictyota in four of six contrasts. When collected from a deeper offshore site, it - was significantly less palatable than the tropical species in four of six contrasts. Thus, for this species, the between-population variance in palatability within a geographic region (North Carolina) bracketed the variance in palatability that we found among species and between regions.
\end{abstract}

Feeding assays with both temperate and tropical urchins produced similar results, indicating that choices were made based on fundamental characteristics of the algae rather than on greater familiarity with local prey species. To see if chemical defenses could explain the differences in herbivore resistance that we noted using freeze-dried algae, we tested the effects of lipid-soluble and water-soluble extracts from each alga on urchin feeding by incorporating extracts into a standard palatable food. We also measured protein content and percent ash-free dry mass of the seaweeds in order to correlate urchin feeding preferences with these measures of food quality. Lipophilic chemical extracts explained urchin preferences in 9 of $15(60 \%)$ North Carolina-Bahamas contrasts. Water-soluble extracts, protein content, and percent ash-free dry mass generally did not account for feeding patterns seen in the original assays. Our results support the general hypothesis that tropical seaweeds have stronger chemical defenses than temperate seaweeds. For some genera, however, smaller-scale local variability in herbivore resistance within a species can be as striking as overall latitudinal differences.

Key words: algae; Arbacia; chemical defenses; Dictyota; geographic pattern; plant-herbivore interactions; sea urchin; seaweeds; temperate vs. tropical.

\section{INTRODUCTION}

Tropical plants are hypothesized to have stronger defenses against herbivory than temperate plants due to the perceived increase in grazing intensity at lower latitudes (Levin and York 1978, Vermeij 1978, Fenical 1980, Gaines and Lubchenco 1982, Faulkner 1984, Hay and Fenical 1988, Coley and Aide 1990, Hay 1991).

\footnotetext{
${ }^{1}$ Manuscript received 27 April 1995; revised 12 January 1996; accepted 30 January 1996; final version received 26 February 1996.

${ }^{2}$ Address correspondence to this author.
}

Grazing on tropical coral reefs is thought to be more intense than in any other marine or terrestrial community (Carpenter 1986, Hay 1991, Hay and Steinberg 1992), and herbivory by reef fishes (reviewed by Horn 1989, Hay 1991) is thought to have selected for increased chemical and morphological defenses among tropical seaweeds (Hay 1981, 1991, Gaines and Lubchenco 1982, Steneck 1986, Duffy and Hay 1990, Hay and Steinberg 1992, Paul 1992). Tropical algae generally produce more kinds, and higher concentrations, of secondary metabolites than do temperate plants (Fenical 1980, Faulkner 1984), and many of these com- 
pounds have been found to deter a variety of marine herbivores (reviewed by Hay and Fenical 1988, Hay 1991, Paul 1992).

Along with herbivory, predation pressure also is hypothesized to increase with decreasing latitude. Supporting evidence for both phenomena comes from a wide range of terrestrial and marine systems, and includes temperate-tropical comparisons of the secondary metabolites of sponges and sea cucumbers (Bakus and Green 1974), protective shell architecture of gastropods (Vermeij 1978), predation by ants on wasp larvae (Jeanne 1979), predation by marine fish on gastropods (Bertness et al. 1981), predation on sessile biota in rocky intertidal habitats (Menge and Lubchenco 1981), predation on marine decapod crustaceans (Heck and Wilson 1987), and insect damage and levels of phenolics in forest trees (Coley and Aide 1990). These diverse studies suggest that the intensity of herbivory and predation is greater, and levels of prey defense are possibly higher, in tropical than in temperate habitats.

Very little direct, experimental evidence exists, however, to support the hypothesis that temperate prey are really more susceptible to consumers, or that tropical prey have more strongly developed defenses. Numerous findings suggest the need to more rigorously investigate the hypothesized latitudinal trend in prey defenses, or susceptibility to consumers. For example, although antiherbivore defense is often seen as the "raison d'etre" of plant secondary metabolites (Herms and Mattson 1992), not all seaweed secondary metabolites act as feeding deterrents, the deterrent effects of compounds are not always consistent against different herbivores, and secondary metabolites can have functions other than defense against herbivores (Hay and Steinberg 1992, Paul 1992, Steinberg and Van Altena 1992, Schmitt et al. 1995). Thus, latitudinal patterns in the occurrence of secondary metabolites need not be related to patterns in antiherbivore defense alone. The idea that herbivorous fishes exert much greater selective pressure on tropical than on temperate seaweeds could be an artifact caused by a general lack of knowledge about the ecology of temperate herbivorous fishes (Choat 1982, Horn 1989). Additionally, the impact of marine herbivores everywhere is undeniably patchy (Hay 1981, 1985, 1991, Gaines and Lubchenco 1982, Carpenter 1986, Lewis 1986, Schiel and Foster 1986, Morrison 1988, Steinberg et al. 1995), and such local and regional variability could ultimately overwhelm the proposed general differences between temperate and tropical latitudes.

There are also studies suggesting that herbivores respond to plant nutritional quality as well as defensive characteristics (Mattson 1980, Horn and Neighbors 1984, Duffy and Paul 1992, Hay et al. 1994). Plant quality may even alter the effectiveness of chemical or structural defenses (Duffy and Paul 1992, Hay et al. 1994); hence, attractive, as well as deterrent, characteristics of plants must be considered in determining how plants coexist with herbivores. Scientists cannot interpret a higher incidence of secondary compounds in tropical vs. temperate algae as greater defense of tropical algae without documenting the deterrent effects of the compounds and also considering the nutritional value of the plants. Direct data are needed on the relative susceptibility of temperate vs. tropical plants to herbivores, not simply on plant characteristics that are assumed to function as defenses against consumers.

The goal of our study was to experimentally investigate the susceptibility to herbivory of similar temperate vs. tropical algae, and to take a first step in delineating mechanisms that produce the feeding patterns we documented. We addressed the following questions regarding a broad range of seaweed taxa: (1) Are tropical seaweeds less palatable to generalist herbivores than their temperate relatives? (2) If so, is this pattern due to chemical defenses? (3) Do temperate and tropical algae differ in their nutritional value, and does this help to explain any latitudinal trends in palatability?

\section{Methods}

\section{Rationale and general approach}

Seaweed resistance to herbivores can vary due to chemical, structural, morphological, and other plant characteristics (Duffy and Hay 1990, Hay 1991, Hay and Steinberg 1992). Because previous speculation on temperate-tropical differences in plant susceptibility to herbivores has focused mainly on chemical defenses (Levin and York 1978, Fenical 1980, Hay and Fenical 1988, Coley and Aide 1990), and because many common herbivores such as parrotfish and sea urchins are able to consume even very tough, calcified seaweeds (Steneck and Adey 1976, Morrison 1988), we chose to test primarily chemical aspects of the seaweeds we studied. Thus, we destroyed any morphological differences between plants by freeze-drying and grinding them to a fine powder before they were embedded in an agar matrix and presented to herbivores. Additionally, logistical constraints imposed by comparing plants from sites separated by $\approx 1200 \mathrm{~km}$ prevented us from using fresh, living plants in our feeding assays.

For most assays, seaweed tissues from North Carolina and from the Bahamas were paired by genus (e.g., a North Carolina Sargassum with a Bahamian Sargassum) and presented to the temperate sea urchin Arbacia punctulata or the tropical sea urchin Lytechinus variegatus. Two seaweeds (Lobophora variegata and Udotea cyathiformis) grew in both regions, and thus allowed within-species contrasts. As a reasonable limit on the number and type of possible feeding experiments, we conducted only within-species or withingenera feeding contrasts. We chose sea urchins as test organisms because they are generalist feeders that commonly influence algal community structure (Lawrence 1975, Carpenter 1986, Lessios 1988) and exhibit clear 
food preferences in the field and laboratory (Lawrence 1975, Vadas 1977, Hay et al. 1986). After assaying the palatability of freeze-dried, finely ground algal tissues, we treated a standard palatable food with lipophilic or water-soluble extracts from these same algal tissues and compared these foods in urchin assays. We used these assay results to determine whether or not chemical defenses could explain the initial differences we observed in palatability. We also measured protein content and percent ash-free dry mass of each alga as a proxy for nutritional value, and attempted to correlate herbivore preference with these aspects of plant quality.

\section{Algal collections}

Tropical algae were collected from five Bahamian islands during a research cruise aboard the $R V$ Columbus Iselin from 16 August to 6 September 1993. The collection sites $(n=8)$ were $<1 \mathrm{~m}$ to $30 \mathrm{~m}$ in depth and spanned a wide variety of subtidal habitats, from mangrove channels to deep reef walls. At each site, we attempted to collect every abundant seaweed that might also occur in North Carolina, or have a congener occurring there. Temperate algae were collected subtidally from four different sites, including an inshore rock jetty (0-3 m depth; see Hay 1986 for a site description) and several hardbottom reefs (17-33 m depth; see Miller and Hay 1996 for site descriptions) off the North Carolina coast during September and October 1993. By spreading our collections over depths of 1-33 $\mathrm{m}$ and across 4-8 sites within each region, we hoped to achieve collections that were crudely representative of each region, rather than of any particular site within a region. Algae from both temperate and tropical regions were kept in coolers or in flowing seawater for $\leq 12 \mathrm{~h}$ after collection, until the plants were sorted, cleaned of epibiota, and wet-frozen $\left(-20^{\circ} \mathrm{C}\right)$. When algae from shipboard freezers were returned to the lab, they were transferred to $\mathrm{a}-70^{\circ} \mathrm{C}$ freezer to minimize changes in algal secondary chemistry. All feeding experiments and subsequent work took place at the Institute of Marine Sciences in Morehead City, North Carolina, USA.

Before freezing the algae, we took voucher samples of each collection and preserved them in $10 \%$ formalin for species identification. Thin-layer chromatography (TLC) was performed on extracts from fresh plants and on extracts from the freeze-dried material we used in feeding assays. These TLC results could be used to check for qualitative differences in plant secondary metabolites due to chemical decomposition during storage or processing (see Cronin et al. 1995). Crude lipophilic extracts were obtained by extracting plants, or freezedried tissue, in $1: 1$ methanol:dichloromethane (MeOH:DCM). Three separate TLC plates spotted with these extracts were then run in three different solvent mixtures ( $1: 1$ ether: hexanes, $100 \%$ ether, and 19:1 ether: methanol) to visualize a range of polarities of algal metabolites, examined under UV light, and charred with sulfuric acid. See the Appendix for a more detailed description of the TLC work on each species used in this study, and current knowledge of each species' secondary chemistry.

\section{Urchin feeding assays using "artificial algae”}

We prepared test food by freeze-drying a portion of each algal collection and grinding it into a fine powder in a small coffee grinder. Powdered algae were reconstituted in agar at a standard dry mass/volume ratio of $0.10 \mathrm{~g}$ alga/mL artificial food (this was reduced to 0.05 $\mathrm{g} / \mathrm{mL}$ for Lobophora variegata because the gel would not set properly with this alga at the higher concentration). Processing algae into agar-based foods limited the variables potentially differing between tropical and temperate plants to algal chemistry and food value (i.e., morphological variability was removed and dry mass/volume ratios were made equivalent). It is, however, unlikely that morphology or structure of the live plants differed much between seaweeds from North Carolina and the Bahamas, because we compared only species within the same genus. For several of the genera we examined, the naturally occurring dry mass/volume of live plants is greater than that we can create in our agar-based foods (M. E. Hay, unpublished data), because the agar will not set properly when natural dry mass/volume ratios are used. Although dry mass concentrations can differ somewhat between congeneric seaweeds (M. E. Hay, unpublished data), we equalized the amount of algal tissue per volume for our test foods.

A typical procedure for making assay foods consisted of boiling $0.36 \mathrm{~g}$ of agar in $10 \mathrm{~mL}$ of distilled water, then adding a slurry of $2 \mathrm{~g}$ of powdered alga in $8 \mathrm{~mL}$ of room temperature distilled water. We poured this warm mixture into one section of a flat, rectangular, formica mold with two lengthwise slits cut out of it. Beneath the mold was a window screen to which the food would become attached as it cooled. A second mixture made with a different alga was poured into the second, parallel, section of the mold. In this manner, two agar-based foods made from different species or populations of algae were attached to a screen that we sliced into strips, each of which contained equal amounts of both choices. For a typical food strip, each choice would cover $8 \times 8$ squares of the screen mesh (see Hay et al. 1994 for an illustration of the mold and the food it produced).

We offered the test foods to individual urchins housed in perforated, plastic 1-L containers that were kept in flowing seawater tables and cleaned frequently. Before each assay, urchins were fed a mixture of palatable green and red algae for 7-24 h; these algae were removed immediately before the assay began. After placing food strips with 30-60 separate urchins, we checked them periodically and attempted to remove strips when about half of either choice was eaten. Allowing urchins to feed beyond this point could obscure their relative preference between the two foods. We 
tried to avoid monitoring the urchins too frequently, because this could disrupt urchin feeding. Assays ran for variable periods, ranging from 3 to $23 \mathrm{~h}$. We generally started an assay during the afternoon, checked urchins $1-1.5 \mathrm{~h}$ after the beginning, and then once every $2-3 \mathrm{~h}$ until an adequate sample size (15-20 urchins, each with one strip) was obtained, usually late at night. The next morning, we removed the remaining strips, often obtaining additional, useful replicates, although several replicates may have been untouched or completely eaten by this time. Preferences between test foods are obscured if most of both foods, or very little of either, is eaten. Therefore, we excluded from the final analyses those replicates for which $<10 \%$ or $>90 \%$ of the total available surface area of the food was consumed. This resulted in sample sizes of 14-50 urchins for the various assays.

We measured the amount of agar-based food consumed by counting the number of window screen squares completely revealed by urchin grazing (see Hay et al. 1994 for an elaboration on methods). Partially uncovered squares were not considered eaten. Differences between North Carolina and Bahamian algae in numbers of squares eaten were statistically analyzed by Wilcoxon signed-ranks tests because the data rarely were normally distributed. Based on the hypothesis that tropical seaweeds should be more resistant to herbivory and, thus, should be eaten less than their temperate relatives, we used directed $P$ values as recommended by Rice and Gaines (1994). This procedure has less power than a traditional one-tailed test, but it allows for statistical evaluation of differences in the direction opposite that predicted.

In addition to testing North Carolina vs. Bahamian algae, we also conducted a few intraspecific comparisons of seaweeds collected from different sites within a geographic region. This provided the opportunity to examine how algal susceptibility to herbivory varied at local, as well as broad, geographic scales. For example, we conducted a paired-choice assay with two separate collections of North Carolina Dictyota menstrualis, one from a shallow inshore jetty, the other from a $17 \mathrm{~m}$ deep rock ledge $8 \mathrm{~km}$ offshore. Such intraspecific comparisons were possible for five species. In these cases, we report two-tailed $P$ values from Wilcoxon signed-ranks tests.

Most of our data was generated using the sea urchin Arbacia punctulata, which is found primarily in temperate waters. To address the possibility that temperate herbivores prefer temperate seaweeds due to previous conditioning, we repeated a number of assays using the tropical urchin Lytechinus variegatus, which had been shipped to North Carolina from tropical habitats near Key Largo, Florida. We placed the urchins in flowing seawater tables, maintained water temperature at $25^{\circ} \mathrm{C}$, and allowed the animals $\approx 1$ wk to recover from transit before starting our assays. Our methods were identical to those used in Arbacia assays, except that we offered
Lytechinus greater total amounts of test food because of their larger body size.

\section{Feeding assays using algal extracts}

To determine whether or not algal chemistry (crude lipophilic or water-soluble extracts) could explain the differential susceptibility of North Carolina vs. Bahamian algae, we took extracts from species from feeding assays in which Arbacia showed significant, or near significant $\left(P_{\mathrm{dir}}=0.100\right.$ in one case $)$, preferences for one alga over the other. Chemical extracts from the freeze-dried, powdered algae were incorporated into agar strips containing the palatable alga Ulva sp. and were retested with Arbacia (see Hay et al. 1994 for methods).

For assays with lipophilic crude extracts, freezedried algal material was extracted with 1:1 ethyl acetate : methanol, spun in a centrifuge, and the supernatant collected. This was repeated three times with aliquots totaling $50 \mathrm{~mL}$ of solvent. The amount of algal material extracted ( $2 \mathrm{~g}$ for most seaweeds; $1 \mathrm{~g}$ for $L o$ bophora) was equivalent to the amount of freeze-dried Ulva onto which the algal extract would be coated. After the initial extraction, solvents were removed by rotary evaporation and the ether-soluble portion of the residue was removed in ether. Lipophilic extracts of North Carolina and Bahamian species were then dissolved in ether and mixed separately into freeze-dried, powdered Ulva. Ether was removed from the extractUlva mixture by rotary evaporation, and the resulting powdered Ulva (now coated with the extract) was used in the standard recipe for feeding assays described in the previous section. The assays used 30-60 Arbacia and typically ran for 1-6 h (except for one Dictyota extract assay that ran for $21 \mathrm{~h}$ due to slow feeding by the urchins). Final sample sizes ranged from 17-53 urchins.

Although considerable research has implicated lipophilic, or nonpolar, secondary metabolites as the major source of seaweed chemical defenses in tropical and subtropical algae (Hay and Fenical 1988, Hay 1991, Paul 1992, Steinberg and van Altena 1992), we wished to test the water-soluble components of the seaweeds in this study for the sake of thoroughness and experimental rigor. Water-soluble extracts were obtained by three successive extractions of $2 \mathrm{~g}$ of freeze-dried, powdered algae ( $1 \mathrm{~g}$ of Lobophora) with $10 \mathrm{~mL}$ of distilled water. Water-algal slurries were spun in a Centra-7 Centrifuge for $20 \mathrm{~min}$ at $2800 \mathrm{rpm}$, and the supernatant solution was collected. When necessary, we filtered these extracts to remove residual particulates, treating both species in a pair similarly. Extracts were frozen at $-70^{\circ} \mathrm{C}$ and placed in a Savant Speed Vac for several hours until the volumes of water were reduced to $<8$ $\mathrm{mL}$. The extracts (plus enough distilled water to equal $8 \mathrm{~mL}$ ) were mixed separately into $2 \mathrm{~g}$ of Ulva sp. (1 $\mathrm{g}$ for Lobophora extracts). A boiled agar-water mixture (10 $\mathrm{mL} \mathrm{H}_{2} \mathrm{O}+0.36 \mathrm{~g}$ agar) was added to each extract- 
Ulva mixture, and the foods were poured into the mold as described previously.

The North Carolina collection of Dictyota menstrualis from $8 \mathrm{~km}$ offshore was depleted before we had performed two of our planned comparisons using water-soluble extracts: $D$. menstrualis $(8 \mathrm{~km}$ offshore North Carolina) vs. D. caribea (Acklins Island, Bahamas), and $D$. menstrualis ( $8 \mathrm{~km}$ offshore North Carolina) vs. D. mertensii (Stocking Island, Bahamas). In order to complete these assays, we used water-soluble extracts from samples and residues that had previously been used to obtain the ether-soluble (i.e., lipophilic) extracts. These samples were processed as described, except that trace amounts of organic solvents were removed from the water extracts under vacuum, and the extracts were frozen at $-70^{\circ} \mathrm{C}$, freeze-dried, and dissolved in distilled water before we added them to the Ulva.

Phlorotannins are the major class of relatively polar (i.e., water-soluble), algal metabolites known to deter some herbivores (Steinberg 1988, Van Alstyne and Paul 1990, Steinberg 1992, but see Steinberg and van Altena 1992). Efficient extraction of these compounds usually requires methanol/water mixtures; therefore, our water extraction probably undersampled these compounds. Also, incorporating water-soluble extracts into an agarbased food and then immersing the food in seawater may allow compounds to leach out of the test food. However, most algal phlorotannins (if they were in our extracts) appear to bind to agar and remain in the food without rapidly being lost to the surrounding water. Steinberg (1988) demonstrated the grazing-deterrent effects of algal phlorotannins by incorporating them into agar and using assays similar to ours, and pointed out that, unlike low molecular mass compounds such as phloroglucinol, high molecular mass phlorotannins remained in agar quite well and could be tested in this manner. However, to minimize leaching by these, or other water-soluble, compounds, we attempted to run the feeding assays as quickly as possible. We used 4045 Arbacia that had been maintained on palatable fresh seaweeds except for a 5 $-8 \mathrm{~h}$ period of starvation before the assays, which we began only in the late evenings (a time when we observed urchins to feed most actively). Within $1 \mathrm{~h}$, we almost always obtained a sufficient number $(>15)$ of replicates in which urchins had consumed between $10 \%$ and $90 \%$ of the total amount of food; this short assay duration should have minimized dissolution of water-soluble feeding deterrents. Similar extraction and assay procedures have been used to demonstrate water-soluble feeding deterrents in other seaweeds (E. Cole, M. E. Hay, N. Lindquist, and M. Deal, personal communication).

\section{Nutritional quality}

We measured percent ash-free dry mass and protein content of the algae to determine whether or not feeding assay results could be explained by these measures of food quality. Percent ash-free dry mass was obtained by drying samples of freeze-dried, powdered algae (three replicates from each collection) for $24 \mathrm{~h}$ at $60^{\circ} \mathrm{C}$, then placing them in an ashing oven at $460^{\circ} \mathrm{C}$ for a minimum of $7 \mathrm{~h}$. Subtracting the mass of the ash from the total dry mass and then dividing by the total dry mass yielded percent ash-free dry mass for each alga. We measured algal protein content using the methods of Bradford (1976) against a bovine serum albumin (BSA) standard. Freeze-dried, powdered algal samples (four replicates from each collection) were digested in $1 \mathrm{M} \mathrm{NaOH}$ for $24 \mathrm{~h}$ before the addition of Bradford reagent and subsequent analysis with a Sigma multiwell reader spectrophotometer.

\section{RESUlts}

\section{Feeding assays using "artificial algae"}

If no geographic trend in palatability were to exist, we would expect to see North Carolina algae eaten more than Bahamian algae in $\approx 50 \%$ of our assays. Our findings contrast strongly with this expectation. When 10 pairs of temperate and tropical seaweeds, representing six genera of red, green, and brown seaweeds (not including Dictyota), were incorporated into agarbased diets and fed to Arbacia, North Carolina species were consumed in greater quantities than their Bahamian congeners in nine of the 10 assays (Fig. 1A). Six of these differences were statistically significant $\left(P_{\mathrm{dir}}\right.$ $\leq 0.05$, Wilcoxon signed-ranks test). For the single case in which the Bahamian choice was preferred, the difference was small and nonsignificant $\left(P_{\mathrm{dir}}=0.997\right.$; Fig. 1A).

Contrasts among species within the brown algal genus Dictyota are presented separately because they made up the majority of our assays (18 of 28 total) and produced highly variable results. Figs. 1B-D show contrasts of three North Carolina collections of Dictyota vs. 6 spp. of Dictyota from the Bahamas. North Carolina Dictyota menstrualis from the shallow, inshore jetty was always consumed more than Bahamian species, with four of the six comparisons being statistically significant $\left(P_{\mathrm{dir}}<0.05\right.$, Wilcoxon signed-ranks test; Fig. 1B). In stark contrast, when D. menstrualis was collected from a $17 \mathrm{~m}$ deep reef $8 \mathrm{~km}$ offshore, urchins consumed less of this collection than of the six tropical species, again with four of the six contrasts differing significantly $\left(P_{\mathrm{dir}}<0.01\right.$, Wilcoxon signed-ranks test; Fig. 1C). In contrast to these strong, but opposing, patterns for D. menstrualis collected from two different locations in North Carolina, D. ciliolata from North Carolina was not consistently more or less palatable than the Bahamian species (Fig. 1D). It was significantly more palatable in one case, significantly less palatable in another case, and showed small and nonsignificant differences in the four remaining contrasts.

To determine whether or not North Carolina seaweeds were, in general, more palatable to Arbacia than 
Amount Eaten (\%)

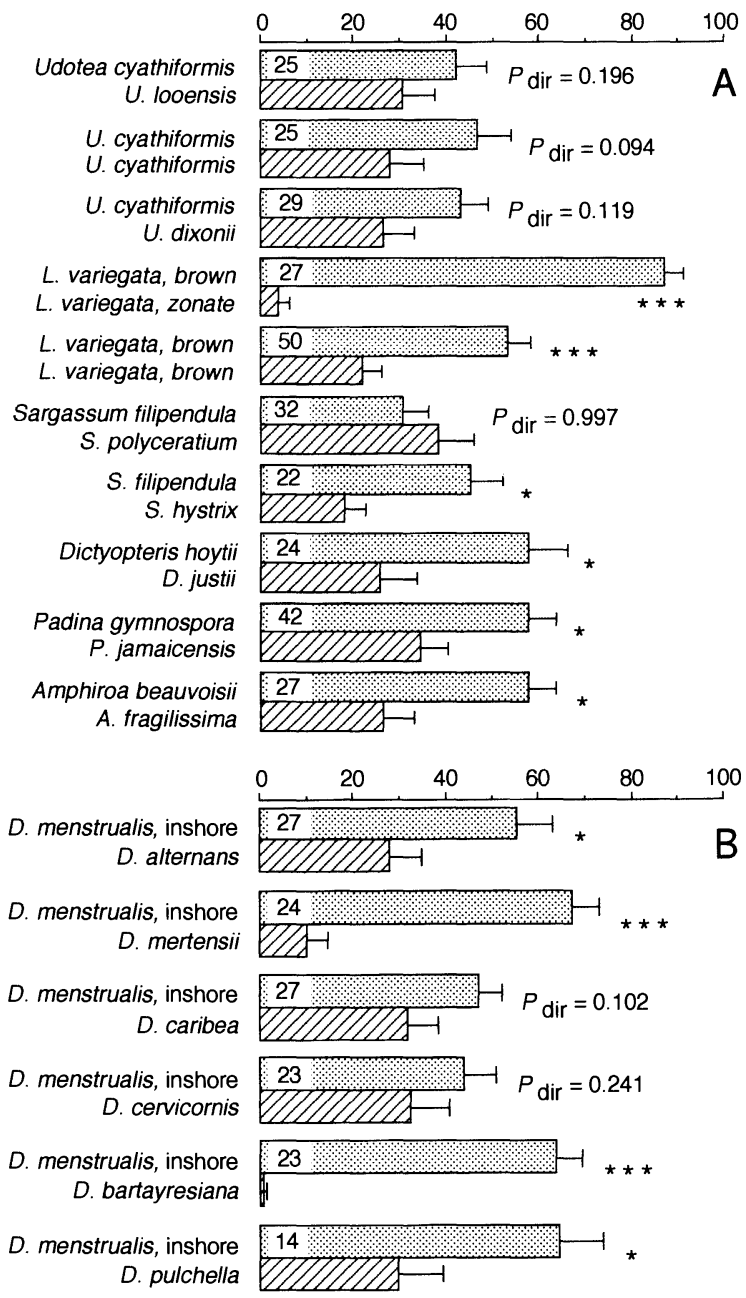

Amount Eaten (\%)

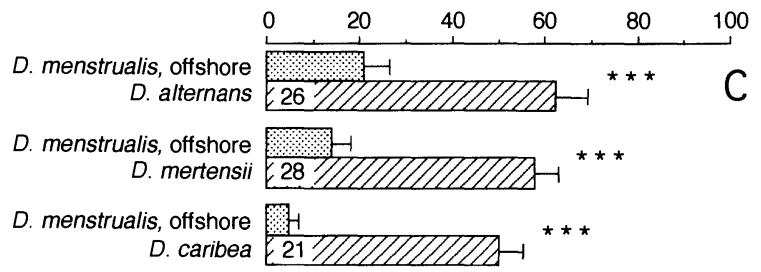

D. menstrualis, offshore D. cervicornis

D. menstrualis, offshore D. bartayresiana

D. menstrualis, offshore D. pulchella
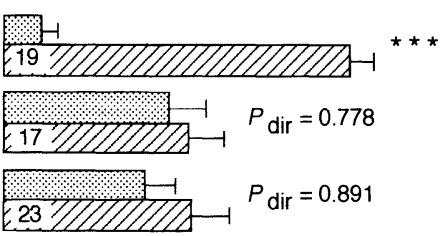

North Carolina Bahamas

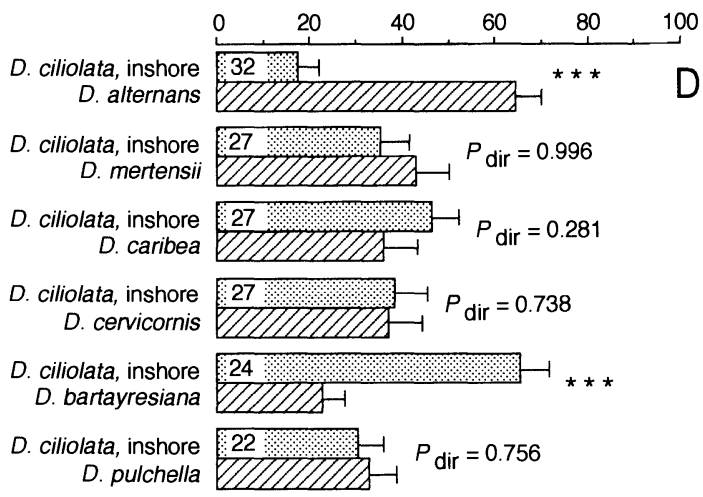

FIG. 1. Feeding $(\bar{X}+1 \mathrm{SE})$ by the sea urchin Arbacia punctulata when offered congeneric pairings of temperate vs. tropical seaweeds that had been freeze-dried, ground to a fine powder, and mixed into an agar matrix. (A) Species contrasts from six genera of red, green, and brown algae, not including Dictyota. (B) Contrasts of Dictyota menstrualis from inshore North Carolina with $6 \mathrm{spp}$. of Dictyota from the Bahamas. (C) Contrasts of Dictyota menstrualis from $8 \mathrm{~km}$ offshore North Carolina with $6 \mathrm{spp}$. of Dictyota from the Bahamas. (D) Contrasts of Dictyota ciliolata from inshore North Carolina with 6 spp. of Dictyota from the Bahamas. All $P$ values are directed $(\gamma / \alpha=0.8$, see Rice and Gaines 1994), with the expectation that tropical algae are less palatable than temperate algae. ${ }^{*} P_{\mathrm{dir}} \leq 0.05 ; * * P_{\mathrm{dir}} \leq 0.01 ; * * * P_{\mathrm{dir}} \leq 0.001$. Sample sizes are given at the base of each pair of bars.

were related Bahamian seaweeds, we pooled the mean amount eaten per assay for all North Carolina species within a genus, and for all Bahamian species within a genus (see Fig. 2). The genera means for North Carolina and the Bahamas were then treated as separate, independent comparisons. This procedure avoided problems of independence and also gave equal consideration to each genus, without biasing the data in favor of genera we had sampled more intensively (particularly Dictyota, which made up 18 of 28 total contrasts). Using the data shown in Fig. 2, we compared the consumption of North Carolina and Bahamian congeners and found a statistically significant $\left(P_{\mathrm{dir}}=0.0175, n\right.$ $=7$; Wilcoxon signed-ranks test) pattern: temperate seaweeds were more palatable to the temperate urchin (Fig. 2). In six of seven within-genera contrasts, North Carolina seaweeds were consumed in greater amounts than related Bahamian seaweeds. On average, Arbacia ate about twice as much temperate as tropical algae.

In addition to comparing seaweeds from different geographic regions, we also conducted a limited number of contrasts comparing the same species collected from separate sites within a geographic region (Fig. 3). For three of the five species we examined, Arbacia feeding differed significantly between two populations of the same species within a geographic region. As examples, North Carolina Dictyota menstrualis from an inshore jetty was consumed about four times more 
Amount Eaten (\%)

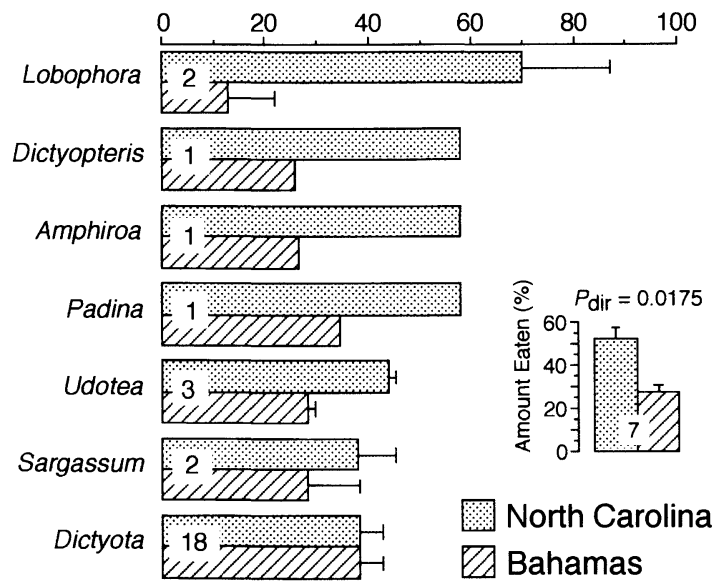

FIG. 2. General pattern of Arbacia feeding for the seven genera where intrageneric comparisons could be made between temperate and tropical species or collections. For Dictyopteris, Amphiroa, and Padina, assays consisted of only one temperate and one tropical species. For the other genera, where contrasts among several species had been assayed, the bars represent mean results (+1 SE) using each separate entire assay (i.e., bars in Fig. 1) as one independent sample. The number at the base of each pair of bars indicates the number of separate assays within each genus. Urchins significantly preferred temperate over tropical algae $\left(P_{\mathrm{dir}}=0.0175\right.$, Wilcoxon signed-ranks test, $n=7$ ).

than the same species growing on an offshore North Carolina reef at a depth of $17 \mathrm{~m}$; Lobophora variegata from a $27 \mathrm{~m}$ deep North Carolina reef with clear water was eaten about four times more than the same species growing on a $17 \mathrm{~m}$ deep North Carolina reef with turbid water (Fig. 3). These results indicate that considerable variation in palatability can also occur between local populations of a single species. The dramatic difference in palatability of Dictyota menstrualis from the inshore jetty vs. the offshore reef, coupled with some morphological differences between plants from these two sites (offshore reef plants commonly had proliferations along blade margins, whereas those from the inshore jetty did not), suggested that the two samples might have been different species rather than different populations of this taxonomically difficult group. However, consultation with an expert in algal taxonomy (Dr. Suzanne Fredericq) and qualitative analyses of secondary metabolites both indicated that we were dealing with a single species. D. menstrualis differs from other local species of Dictyota in producing a specific qualitative combination of diterpenes (pachydictyol A, dictyol E, and dictyodial) (Cronin et al. 1995). Plants from both the inshore jetty and offshore reef did produce these compounds, although concentrations appeared to be higher in plants from offshore (G. Cronin, personal communication; see Appendix).

To see if the preference of Arbacia for temperate over tropical seaweeds (Fig. 2) was due to its greater familiarity with temperate species or to temperate seaweeds being fundamentally more palatable, we repeated 10 of our initial assays using the tropical urchin Lytechinus variegatus. We asked if Lytechinus preferred tropical seaweeds with which it was more familiar, or if its preferences were similar to those of Arbacia. We chose assays representing each genus in which Arbacia had shown a statistically significant preference, as well as three contrasts in which Arbacia showed no statistically significant preference. In eight of these 10 cases, the pattern of food choice was similar for both the temperate and the tropical urchin (Table 1). We found no indication that Lytechinus from the tropical environment of Key Largo, Florida ate more tropical than temperate algae. In fact, there was a significant, positive correlation between the feeding choices of the two urchin species $\left(r=0.791, P_{\text {two-tailed }}\right.$ $=0.0045$, Fisher's $r$ to $z$; Fig. 4), suggesting that both urchins were responding to fundamental plant qualities rather than to differential familiarity with either temperate or tropical seaweeds. One particularly important case is the intraspecific comparison of inshore and offshore Dictyota menstrualis from North Carolina (see asterisk in Fig. 4). The possibility existed that the Arbacia we collected from the same jetty as the inshore alga preferred inshore to offshore algal material due to previous experience; however, Lytechinus also preferred inshore to offshore $D$. menstrualis, but could have had no previous experience with either population. This suggests that the preference was due to inherent characteristics of the algae.

Urchins could have been differentiating between foods on the basis of negative (e.g., chemical defenses, low food value) or positive qualities (e.g., high food value, feeding stimulants) of the seaweeds. We attempted to examine these qualities separately by assaying the effects of chemical extracts on urchin feeding and by measuring food value (protein and \% ash-

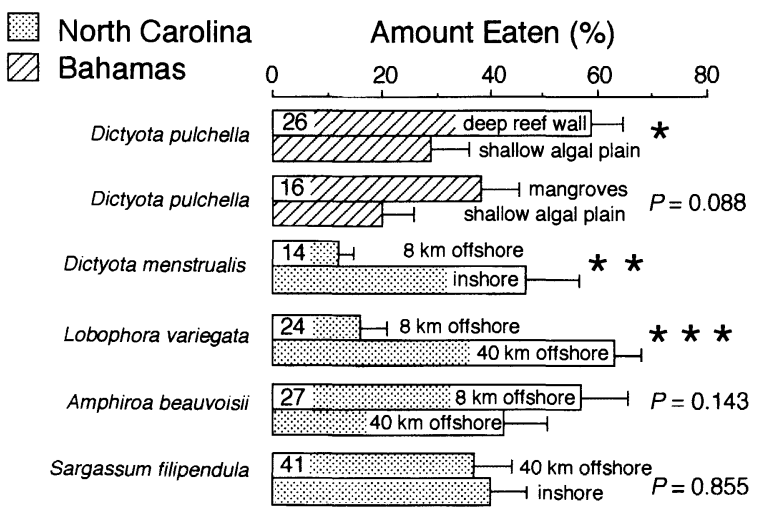

FIG. 3. Arbacia punctulata feeding $(\bar{X}+1$ SE) assays comparing conspecific collections of seaweeds from different sites within a geographic region. Site designations are located adjacent to or within each bar. Sample sizes are given at the base of each pair of bars. $P$ values are two-tailed (Wilcoxon signed-ranks test). 
TABLE 1. Results of Lytechinus variegatus feeding assays testing freeze-dried, powdered algae in an agar matrix. Direction of feeding is symbolized by arrows: $\uparrow, \%$ North Carolina (NC) alga eaten $>\%$ Bahamian alga eaten; $\downarrow$, \% North Carolina alga eaten $<\%$ Bahamian alga eaten. All $P$ values (Wilcoxon signed-ranks test) are directed.

\begin{tabular}{|c|c|c|c|c|c|}
\hline \multirow[b]{2}{*}{ Species contrast } & \multirow{2}{*}{$\begin{array}{c}\text { Amount eaten } \\
(\%) \\
(\text { Mean } \pm 1 \mathrm{SE})\end{array}$} & \multicolumn{2}{|c|}{ Lytechinus assays } & \multicolumn{2}{|c|}{ Arbacia assays } \\
\hline & & $P_{\mathrm{dir}}$ & $n$ & $P_{\mathrm{dir}}$ & $n$ \\
\hline $\begin{array}{l}\text { Udotea cyathiformis (NC) vs. } \\
\text { U. cyathiformis (Bahamas) }\end{array}$ & $\begin{array}{l}45.5 \pm 6.8 \\
27.1 \pm 5.5\end{array}$ & $0.072 \uparrow$ & 30 & $0.094 \uparrow$ & 25 \\
\hline $\begin{array}{l}\text { Lobophora variegata, "brown blade" (NC) vs. } \\
\text { L. variegata "zonate blade"" (Bahamas) }\end{array}$ & $\begin{array}{l}84.8 \pm 3.7 \\
13.0 \pm 4.3\end{array}$ & $<0.0001 \uparrow$ & 24 & $<0.0001 \uparrow$ & 27 \\
\hline $\begin{array}{l}\text { Sargassum filipendula (NC) vs. } \\
\text { S. hystrix (Bahamas) }\end{array}$ & $\begin{array}{l}56.1 \pm 7.1 \\
37.2 \pm 6.9\end{array}$ & $0.119 \uparrow$ & 27 & $0.013 \uparrow$ & 22 \\
\hline $\begin{array}{l}\text { S. filipendula (NC) vs. } \\
\text { S. polyceratium (Bahamas) }\end{array}$ & $\begin{array}{l}42.9 \pm 6.8 \\
25.5 \pm 5.5\end{array}$ & $0.087 \uparrow$ & 28 & $0.997 \downarrow$ & 32 \\
\hline $\begin{array}{l}\text { Dictyopteris hoytii (NC) vs. } \\
\text { D. justii (Bahamas) }\end{array}$ & $\begin{array}{l}55.9 \pm 6.4 \\
31.5 \pm 6.3\end{array}$ & $0.031 \uparrow$ & 28 & $0.041 \uparrow$ & 24 \\
\hline $\begin{array}{l}\text { Padina gymnospora }(\mathrm{NC}) \mathrm{vs} . \\
P . \text { jamaicensis (Bahamas) }\end{array}$ & $\begin{array}{l}48.0 \pm 7.3 \\
53.7 \pm 6.3\end{array}$ & $0.895 \downarrow$ & 24 & $0.028 \uparrow$ & 42 \\
\hline $\begin{array}{l}\text { Amphiroa beauvoisii (NC) vs. } \\
\text { A. fragilissima (Bahamas) }\end{array}$ & $\begin{array}{l}40.1 \pm 6.5 \\
33.0 \pm 7.0\end{array}$ & $0.421 \uparrow$ & 30 & $0.012 \uparrow$ & 27 \\
\hline $\begin{array}{l}\text { Dictyota menstrualis (inshore NC) vs. } \\
\text { D. bartayresiana (Bahamas) }\end{array}$ & $\begin{array}{l}58.8 \pm 6.7 \\
14.8 \pm 3.4\end{array}$ & $<0.0001 \uparrow$ & 26 & $<0.0001 \uparrow$ & 23 \\
\hline $\begin{array}{l}\text { D. menstrualis (offshore NC) vs. } \\
\text { D. bartayresiana (Bahamas) }\end{array}$ & $\begin{array}{l}20.0 \pm 6.3 \\
53.7 \pm 6.4\end{array}$ & $0.0001 \downarrow$ & 18 & $0.778 \downarrow$ & 17 \\
\hline $\begin{array}{l}\text { D. menstrualis (inshore NC) vs. } \\
D . \text { menstrualis (offshore NC) }\end{array}$ & $\begin{array}{r}47.0 \pm 5.1 \\
1.6 \pm 0.8\end{array}$ & $<0.0001 \uparrow \dagger$ & 18 & $0.007 \uparrow \dagger$ & 14 \\
\hline
\end{tabular}

$\dagger$ Direction of the intraspecific contrast of D. menstrualis from inshore and offshore North Carolina was defined as follows: $\uparrow, \%$ inshore alga eaten $>\%$ offshore alga eaten. $P$ values in this case are two-tailed.

free dry mass), and then determining whether or not these data provided a consistent explanation for the patterns we observed in urchin feeding choices. In other words, did species that were avoided in the agarbased assays yield chemical extracts that reduced feed-

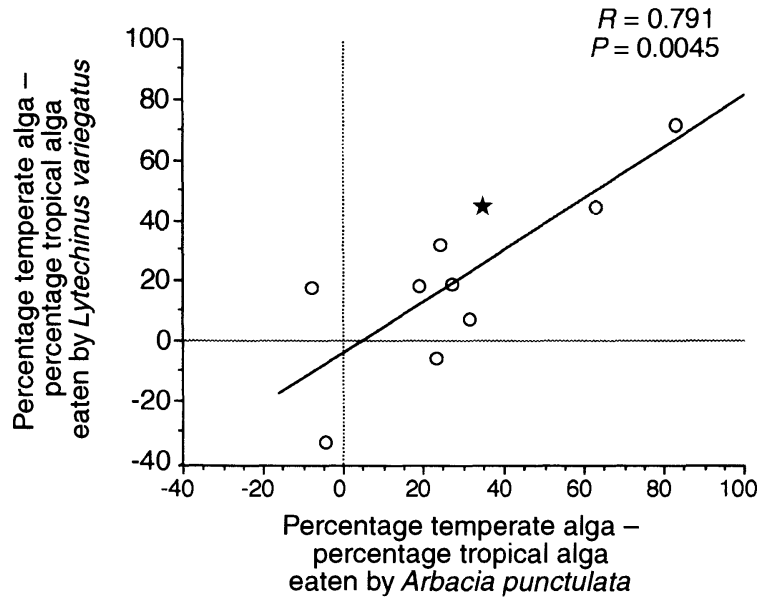

FIG. 4. Plot of the difference in mean amount of temperate vs. tropical seaweed eaten (\% North Carolina algae minus \% Bahamian algae) by Arbacia punctulata and Lytechinus variegatus in equivalent assays. Points represent each of the 10 species contrasts tested with both herbivores. The $\star$ indicates the assay involving Dictyota menstrualis from inshore vs. offshore North Carolina, in which we computed the difference as $\%$ inshore minus \% offshore alga eaten. ing on palatable food, and did low-preference algae contain lower food value (i.e., lower protein content and ash-free dry mass)?

\section{Effects of seaweed extracts on urchin feeding}

Thin-layer chromatograms (TLC) of the seaweeds used in this study did not suggest obvious changes in algal metabolites between algae soon after collection and algae that had been freeze-dried and stored at $-70^{\circ} \mathrm{C}$, with the exception of the Bahamian collection of Udotea cyathiformis (Appendix). Considering the chemical instability of metabolites of this genus (Faulkner 1986, Paul and Fenical 1986), and the fact that extract tests were conducted as long as 5 mo after assays of freeze-dried algae, we did not include tests of Udotea extracts in our analysis of the role of chemical defense in generating the feeding patterns on agarbased algal diets.

When we tested whether or not lipid-soluble or water-soluble extracts from North Carolina vs. Bahamian seaweeds could have caused the significant feeding choices we documented using the powdered algae in agar (Fig. 1), we found that effects of lipid-soluble extracts could explain $\approx 60 \%$ of the significant feeding choices we observed (Fig. 5A) and that effects of watersoluble extracts explained little, if any, of our initial feeding data (Fig. 5B). In 10 of 15 assays with lipophilic extracts, feeding differences were in the same direction as occurred using powdered algae as foods 
(Fig. 5A). In all nine of the assays where extracts significantly differed (or nearly so; $P_{\text {dir }}=0.069$ in one case) in their effects on feeding, changes were in the direction predicted if the less palatable algal food had been avoided because of the plant's lipid-soluble chemical defenses. The majority (six of eight) of the statistically significant contrasts in these assays involved Dictyota. This is not surprising, given the rich secondary chemistry this genus is known to possess (Faulkner 1993, and his previous reviews cited therein) and the documented herbivore deterrence of several Dictyota secondary metabolites (Hay et al. 1987a, b, 1988a, Hay and Steinberg 1992, Duffy and Hay 1994, Cronin and Hay $1996 a, b)$. Only one of 15 contrasts of water-soluble extracts generated a significant difference between the algal pair, and this was in a direction opposite that predicted from the original assay using the powdered algal material (Fig. 5B). In the case of D. menstrualis vs. D. alternans (bottom of Figs. 5A and B), the effect of the water-soluble extracts coincided with patterns in feeding on the powdered algal material, but the effect was not significant $\left(P_{\mathrm{dir}}=0.070\right)$; however, there was a significant, and apparently larger, effect of the lipophilic extracts $\left(P_{\text {dir }}<0.001\right)$. Given that water-soluble compounds should dissolve out of agar-based food more readily than lipid-soluble compounds, and that phlorotannins may have been inefficiently harvested by our extraction procedures, the assays of water-soluble extracts could be overly conservative. However, this type of assay is commonly used to show that watersoluble phlorotannins from brown seaweeds function as feeding deterrents (Steinberg 1985, 1988, Steinberg and van Altena 1992), and dissolution of compounds in our water-soluble extracts was minimized by running the assays for only $1 \mathrm{~h}$.

To evaluate the general relationship between urchin preferences for powdered algae in agar and for Ulvabased diets treated with lipophilic extracts of these algae, we calculated a correlation coefficient for these two variables. First, so that the general pattern would not be overwhelmed by the numerous Dictyota assays, we condensed the Dictyota results into a single mean (i.e., difference in tropical vs. temperate food eaten) for the agar-based algal assays, and a corresponding mean for effects of the extract when placed in Ulvabased food. A positive correlation occurred, although it was not statistically significant for this small sample size $\left(r=0.698, P_{\text {two-tailed }}=0.135\right.$; Fisher's $r$ to $z, n=$ $6)$. A much stronger case for the importance of lipophilic chemistry in explaining original differences in palatability comes from analysis of the Dictyota contrasts alone $\left(r=0.928, P_{\text {two-tailed }}<0.0001\right.$, Fisher's $r$ to $z, n=10)$. D. menstrualis $(8 \mathrm{~km}$ offshore North Carolina), the only temperate plant that was extremely unpalatable in "artificial alga" form, always yielded extracts that were very unpalatable (Fig. 5A).

In contrast to these results for lipophilic extracts, a correlation using the effects of water-soluble extracts was both nonsignificant and negative whether we analyzed the results by genera $\left(r=-0.420 ; P_{\text {two-tailed }}=\right.$ $0.438 ; n=6)$, considered only Dictyota assays $(r=$ $\left.-0.389, P_{\text {two-tailed }}=0.279, n=10\right)$, or treated all assays as separate data points $\left(r=-0.351 ; P_{\text {two-tailed }}=0.186\right.$; $n=15$ ).

\section{Nutritional quality}

Table 2 summarizes the results of protein and percent ash-free dry mass measurements of all the algae we examined in this study. Neither protein content nor percent ash-free dry mass of the freeze-dried, powdered algae was a good predictor of herbivore preference in our feeding assays, considering both inter- and intraspecific contrasts. Urchins did not tend to consume more of the food that had higher percentages of either protein or percent ash-free dry mass. If protein or percent ash-free dry mass was unrelated to feeding preference, then one might expect urchins to choose higher content algae in about half of the feeding trials and to avoid them in about half of the trials. This is what we found for both protein and percent ash-free dry mass. In only 15 of 34 assays using Arbacia and powdered algae in agar (interspecific and intraspecific contrasts) were protein contents of the preferred algae greater than those of the less eaten choice. Ash-free dry masses were even less explanatory (13 of 34 contrasts). We could not detect any correlation between differences in amount of agar-based algae eaten and either the differences in algal protein content (all assays separately: $r=0.017, P_{\text {two-tailed }}=0.927, n=34 ;$ Dictyota assays alone: $r=0.170, P_{\text {two-tailed }}=0.652, n=10$; genera averages: $r=0.055, P_{\text {two-tailed }}=0.918, n=7$ ) or differences in percent ash-free dry mass (all assays separately: $r=0.020, P_{\text {two-tailed }}=0.905, n=34 ;$ Dictyota assays alone: $r=0.307, P_{\text {two-tailed }}=0.402, n=10$; genera means: $\left.r=0.024, P_{\text {two-tailed }}=0.961, n=7\right)$. Results from Lytechinus assays also do not suggest that urchins were selecting on the basis of either protein content ( $r=0.205, P_{\text {two-tailed }}=0.580$, Fisher's $r$ to $z, n$ $=10)$ or percent ash-free dry mass $\left(r=0.148, P_{\text {two- }}\right.$ tailed $=0.694$, Fisher's $r$ to $z, n=10$ ) of the food presented to them.

\section{DISCUSSION}

This study provides a direct test of the hypothesized latitudinal gradient in seaweed palatability and chemical defenses (Fenical 1980, Hay 1981, Hay and Steinberg 1992). We documented a general pattern in which algae from the Bahamas were less palatable to urchins than were closely related algae from North Carolina (Figs. 1A and 2, Table 1), even though all plants had been processed into artificial foods that were morphologically identical. Algae of the genus Dictyota did not support this trend (Fig. 1B-D), but a single population of North Carolina Dictyota accounted for nearly all exceptions to the general pattern. Out of the many temperate and tropical species we compared, we found only 
TABLE 2. Protein content and percent ash-free dry mass of freeze-dried, finely ground seaweeds used in urchin feeding assays. NC, North Carolina.

\begin{tabular}{|c|c|c|c|}
\hline Alga & Location of collection & $\begin{array}{c}\text { Protein } \\
(\% \text { dry mass }) \\
\text { (mean } \pm 1 \text { SE) }\end{array}$ & $\begin{array}{c}\text { Ash-free } \\
\text { dry mass }(\%) \\
(\text { mean } \pm 1 \mathrm{SE})\end{array}$ \\
\hline Udotea cyathiformis & $40 \mathrm{~km}$ offshore, $\mathrm{NC}$ & $0.81 \pm 0.25$ & $24.0 \pm 0.10$ \\
\hline U. cyathiformis & Crooked Island, Bahamas & $0.39 \pm 0.21$ & $17.4 \pm 0.17$ \\
\hline$U$. looensis & Stocking Island, Bahamas & $2.8 \pm 0.07$ & $25.0 \pm 0.17$ \\
\hline$U$. dixonii & Highbourne Key, Bahamas & $1.2 \pm 0.12$ & $32.3 \pm 0.08$ \\
\hline $\begin{array}{l}\text { Lobophora variegata, } \\
\text { "brown blade", }\end{array}$ & $40 \mathrm{~km}$ offshore, $\mathrm{NC}$ & $4.1 \pm 0.16$ & $45.5 \pm 0.33$ \\
\hline $\begin{array}{l}\text { L. variegata, } \\
\text { "brown blade", }\end{array}$ & $8 \mathrm{~km}$ offshore, $\mathrm{NC}$ & $3.5 \pm 0.13$ & $39.5 \pm 0.33$ \\
\hline $\begin{array}{l}\text { L. variegata, } \\
\text { "brown blade", }\end{array}$ & Crooked Island, Bahamas & $4.3 \pm 0.15$ & $58.6 \pm 0.17$ \\
\hline $\begin{array}{l}\text { L. variegata, } \\
\text { "zonate blade", }\end{array}$ & Sweetings Key, Bahamas & $4.3 \pm 0.35$ & $51.0 \pm 0.38$ \\
\hline Sargassum filipendula & $40 \mathrm{~km}$ offshore, $\mathrm{NC}$ & $3.2 \pm 0.21$ & $58.0 \pm 0.05$ \\
\hline S. filipendula & inshore North Carolina & $4.3 \pm 0.21$ & $59.4 \pm 0.15$ \\
\hline S. hystrix & Sweetings Key, Bahamas & $2.9 \pm 0.20$ & $53.4 \pm 0.35$ \\
\hline S. polyceratium & Highbourne Key, Bahamas & $3.0 \pm 0.26$ & $50.4 \pm 0.12$ \\
\hline Dictyopteris hoytii & $40 \mathrm{~km}$ offshore, $\mathrm{NC}$ & $5.2 \pm 0.28$ & $61.4 \pm 0.95$ \\
\hline D. justii & Acklins Island, Bahamas & $3.0 \pm 0.10$ & $62.8 \pm 0.35$ \\
\hline Padina gymnospora & inshore North Carolina & $3.0 \pm 0.13$ & $48.2 \pm 0.21$ \\
\hline P. jamaicensis & Acklins Island, Bahamas & $1.5 \pm 0.21$ & $35.2 \pm 0.13$ \\
\hline Amphiroa beauvoisii & $40 \mathrm{~km}$ offshore, $\mathrm{NC}$ & $1.7 \pm 0.07$ & $19.1 \pm 0.18$ \\
\hline A. beauvoisii & $8 \mathrm{~km}$ offshore, $\mathrm{NC}$ & $2.0 \pm 0.27$ & $19.9 \pm 0.03$ \\
\hline A. fragilissima & Sweetings Key, Bahamas & $1.3 \pm 0.22$ & $19.6 \pm 0.27$ \\
\hline Dictyota menstrualis & inshore North Carolina & $2.5 \pm 0.23$ & $47.8 \pm 0.04$ \\
\hline D. menstrualis & $8 \mathrm{~km}$ offshore, $\mathrm{NC}$ & $1.3 \pm 0.22$ & $49.3 \pm 0.29$ \\
\hline D. ciliolata & inshore North Carolina & $2.6 \pm 0.20$ & $53.2 \pm 0.14$ \\
\hline D. alternans & Acklins Island, Bahamas & $1.0 \pm 0.11$ & $46.3 \pm 0.11$ \\
\hline D. mertensii & Stocking Island, Bahamas & $1.1 \pm 0.15$ & $51.2 \pm 0.19$ \\
\hline D. caribea & Acklins Island, Bahamas & $0.74 \pm 0.09$ & $36.2 \pm 0.13$ \\
\hline D. cervicornis & Acklins Island, Bahamas & $0.17 \pm 0.17$ & $52.9 \pm 0.17$ \\
\hline D. bartayresiana & Sweetings Key, Bahamas & $2.0 \pm 0.12$ & $51.7 \pm 0.04$ \\
\hline D. pulchella & $\begin{array}{l}\text { shallow algal plain, } \\
\text { Sweetings Key, Bahamas }\end{array}$ & $3.0 \pm 0.26$ & $61.8 \pm 0.06$ \\
\hline D. pulchella & $\begin{array}{l}\text { mangrove channel, } \\
\text { Sweetings Key, Bahamas }\end{array}$ & $0.85 \pm 0.19$ & $50.8 \pm 0.15$ \\
\hline D. pulchella & $\begin{array}{l}\text { deep wall reef, Acklins } \\
\text { Island, Bahamas }\end{array}$ & $1.8 \pm 0.11$ & $44.3 \pm 0.31$ \\
\hline
\end{tabular}

this one population of temperate alga that was less palatable and more chemically defended than most of its tropical congeners (Figs. 1 and 5). We found numerous Bahamian seaweeds that were avoided in favor of their temperate relatives (Fig. 1).

Although several species exhibited considerable within-region variance in their palatability to herbivores (Figs. 1 and 3), this did not overwhelm our ability to document a strong between-region pattern, with temperate algae, as a group, being significantly more palatable (Fig. 2). Given that our collections from both North Carolina and the Bahamas came from 4-8 widely separated sites within each region and spanned a broad range of depths and habitats, much of this local variance should have been incorporated into our assays. That such variation did not prevent us from documenting the between-region pattern suggests that the between-region differences are large and relatively consistent.

Although we contrasted only one temperate (North Carolina) with one tropical (the Bahamas) region, there are several reasons to suspect that our findings may be representative of general differences between temperate and tropical seaweeds. First, studies of grazing rates

FIG. 5. Arbacia punctulata feeding $(\bar{X}+1 \mathrm{SE})$ on agar containing freeze-dried Ulva treated with (A) lipophilic crude extracts from the temperate vs. tropical species and (B) water-soluble extracts from these same temperate vs. tropical species. Significance level of original assays using freeze-dried, powdered algae is indicated by asterisks to the left of species names. Arrows to the right of the bars represent directions of extract assays (left-hand arrows) and directions of corresponding original assays (right-hand arrows). $\uparrow$ indicates that urchins ate more of the North Carolina than of the Bahamian choice $\downarrow$ indicates that urchins ate less of the North Carolina than of the Bahamian choice. All $P$ values are directed, with the expectation that algal extracts affect feeding in the same direction as freeze-dried algal tissue. Lobophora variegata is the "brown-bladed" form. Shadings are as in Figs. 1-3. 
A

Amount Eaten (\%)

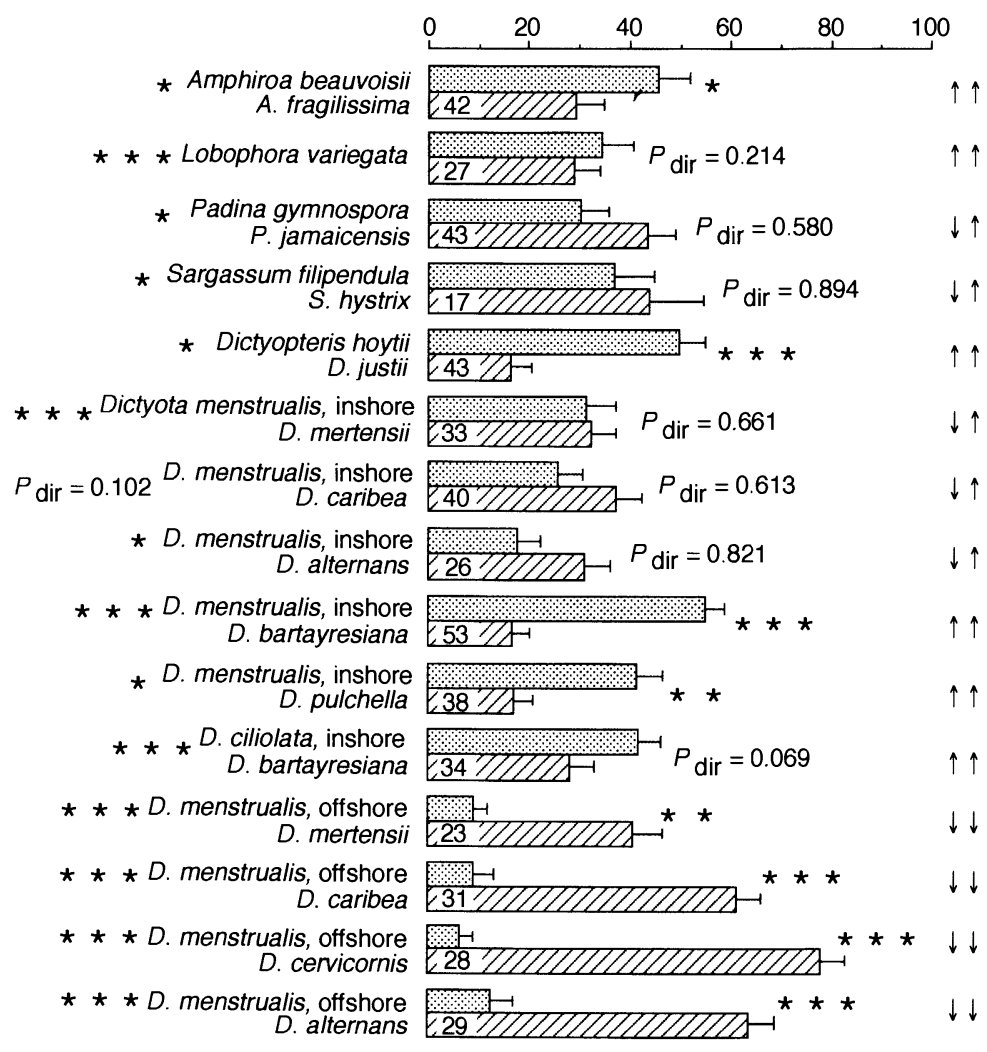

B

Amount Eaten (\%)

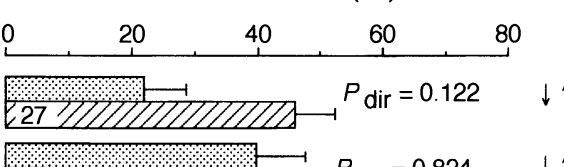

$\star \star \star$ Lobophora variegata

* Padina gymnospora $P$. jamaicensis

* Sargassum filipendula S. hystrix

* Dictyopteris hoyti D. justii

* * * Dictyota menstrualis, inshore D. mertensii $P_{\text {dir }}=0.102 D$. menstrualis, inshore

* D. menstrualis, inshore $D$. alternans 28 P $P$ dir $=0.824 \quad \downarrow \uparrow$
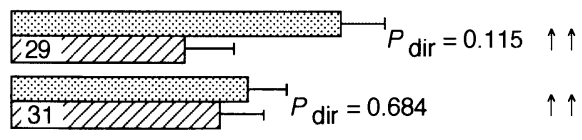

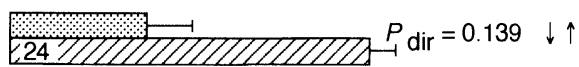
$P_{\text {dir }}=0.528 \quad \downarrow \uparrow$

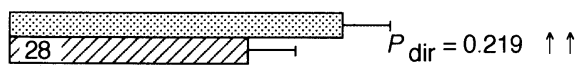
22 P $P$ dir $P$

$\star \star \star D$. menstrualis, inshore $D$. bartayresiana

* D. menstrualis, inshore $D$. pulchella

$\star \star \star D$. ciliolata, inshore D. bartayresiana $\star \star \star D$. menstrualis, offshore D. mertensii

$\star \star \star D$. menstrualis, offshore D. caribea $\star \star \star D$. menstrualis, offshore D. cervicornis $D$. alternans 
on tropical reefs worldwide have consistently documented very high rates of plant removal relative to those seen in temperate habitats (Hatcher and Larkum 1983, Carpenter 1986, review by Hay 1991). Second, overviews by natural products chemists (Fenical 1980, Faulkner 1993 and earlier reviews cited therein) have consistently noted the greater diversity and concentration of bioactive metabolites in tropical than in temperate marine organisms. Third, ecological studies of tropical seaweeds have consistently found that many produce lipophilic chemical defenses against herbivores (reviewed by Hay 1991, Hay and Steinberg 1992, Paul 1992).

All of the above patterns suggest that our North Carolina-Bahamas contrast may be representative of temperate-tropical contrasts in general; however, this broader assumption should be treated as a hypothesis rather than a conclusion. To illustrate this point, initial findings that tropical brown seaweeds produced fewer polyphenolics than temperate seaweeds appeared to be well established based on data contrasting temperate vs. tropical areas of the Pacific (Steinberg 1989, 1992, Steinberg and Paul 1990). However, recent findings of high phenolic concentrations in numerous brown seaweeds from the tropical Caribbean indicate that this supposedly temperate-tropical pattern does not hold for the temperate Atlantic vs. tropical Caribbean (Targett et al. 1992). Expanding studies like ours to include more temperate and tropical sites will allow a more rigorous evaluation of the latitudinal pattern in seaweed palatability and chemical defenses that we document for our sites and that we hypothesize occurs more broadly.

Seaweed secondary metabolites previously had been reported to increase with decreasing latitude (Fenical 1980, Faulkner 1984, Hay and Fenical 1988). This pattern was assumed to indicate greater chemical defenses in tropical compared to temperate seaweeds (Vermeij 1978, Fenical 1980, Faulkner 1984, Paul 1992), but no studies had determined that tropical plants were actually less palatable than their temperate relatives, or that the geographic variation in algal secondary metabolites actually affected plant susceptibility to herbivores. In this study, differential effects of lipophilic extracts from temperate vs. tropical seaweeds (Fig. 5) appeared to explain more than half of the feeding choices we observed; interestingly, this included a few cases in which urchins avoided a North Carolina seaweed, Dictyota menstrualis from offshore. Water-soluble extracts, protein content, and ash content appeared to have little, if any, effect on herbivore feeding choices in our assays. In roughly half the cases we examined (for three of six genera), lipophilic, but not water-soluble, chemical defenses significantly affected urchin selectivity (Fig. 5). This is consistent with other speculation that nonpolar metabolites often appear to be more important in antiherbivore defense than polar, water-soluble compounds (Paul and Hay 1986, Steinberg and Paul 1990, Steinberg and van Altena 1992). Although we did not identify individual compounds in the lipophilic extracts of our seaweeds, there are previous reports of specific metabolites and their deterrent effects on herbivory for several of the algae we examined (Hay 1991, Paul 1992). See the Appendix for information on the secondary metabolites in these seaweeds.

Some studies have suggested that herbivores, including sea urchins, can select among prey on the basis of nutrient value, defined by both the absolute nutrient value of the food (protein and nitrogen; see Horn and Neighbors 1984, Renaud et al. 1990) and the ability of the herbivore to utilize those nutrients (Lawrence 1975, Vadas 1977, Horn and Neighbors 1984; nitrogen limitation reviewed by Mattson 1980). In this study, we found little evidence that either protein content or percent ash-free dry mass of the algal foods was consistently affecting urchin feeding preferences (Table 2). Renaud et al. (1990) hypothesized that urchins used positive cues (i.e., protein content) to select among high-preference seaweeds, and negative cues (i.e., chemical defenses) to select among low-preference seaweeds. Because all the algae we studied appear to be relatively low-preference for generalist herbivores (Hay 1984, Paul and Hay 1986, Hay et al. 1986, 1987a), such a hypothesis might explain the lack of correlation between feeding preferences and either protein or ash content of the food. Neighbors and Horn (1991) found that seaweeds eaten by two temperate, herbivorous fishes were, in general, not nutritionally better than seaweeds that were avoided, and they suggested that traits such as secondary metabolites may be of primary importance for several seaweeds in their study. Our results point to lipophilic chemical defenses as a major mechanism generating as much as $60 \%$ of the differences in palatability between North Carolina and Bahamian seaweeds; however, $\approx 40 \%$ of the feeding patterns we observed remain unexplained.

For those temperate-tropical contrasts in which neither lipophilic nor water-soluble extracts produced feeding differences similar to what we saw using the freeze-dried seaweeds in agar, several explanations are feasible. First, during the time between assays testing agar-based algal foods and assays testing extracts in Ulva and agar-based foods, metabolites responsible for the palatability differences could have broken down. Little is published regarding the effects of various extraction or storage procedures on individual algal compounds (see Cronin et al. 1995), but compounds that are stable in plant tissues can become labile following extraction (W. Fenical, personal communication), and volatile compounds may be lost during freeze-drying, as in some species of Dictyopteris (Hay et al. 1988b). Our extraction procedures also may not have removed some of the bioactive compounds responsible for the feeding differences. For example, phlorotannins are water-soluble, but they extract poorly using water alone 
(P. Steinberg and N. Targett, personal communication), so our assays may fail to adequately assess their effects. As one possible example, Lobophora variegata from the Bahamas was much less palatable than L. variegata from North Carolina (Figs. 1A and 2), and Bahamian collections have extremely high concentrations of phlorotannins compared to those from North Carolina (Targett et al. 1995). Alternatively, chemical defenses occasionally may be based on synergistic effects between different chemicals (Berenbaum and Neal 1985) or between chemical and structural (e.g., calcium carbonate) plant traits (Hay et al. 1994). If our extraction procedures separated compounds that act synergisticaly in plant tissues, this also could have diminished our ability to demonstrate chemical deterrents to feeding.

In addition to the overall differences in palatability of North Carolina and Bahamian seaweeds, we observed several instances of intraspecific, local variability in resistance to grazing (Fig. 3). A few previous experimental studies have shown that grazing pressure correlates well with either inter- or intraspecific algal resistance to herbivory within a habitat or region (Hay et al. 1983, Hay 1984, 1985, Paul and Fenical 1986, Paul and Van Alstyne 1988, Van Alstyne 1988, Coen and Tanner 1989, Cronin and Hay 1996a), suggesting that plant defenses and distributions may develop in response to herbivory on a local scale as well as the hypothesized geographic scale. Plant populations may differ in palatability due to genetic divergence (from selective removal of susceptible individuals in heavily grazed habitats) or induction of increased defenses (Harvell 1990, Baldwin 1990, Cronin and Hay 1996a). Two marine brown algae, including Dictyota, have been shown to induce increased levels of chemical defenses in response to herbivory or clipping (Van Alstyne 1988, Yates and Peckol 1993, Cronin and Hay 1996a), but numerous other attempts to demonstrate induction in both brown and green algae have suggested that induction is rare in seaweeds (Paul and Van Alstyne 1992, Paul 1992, Steinberg 1992, 1994, 1995). Because seaweeds often are attacked by large, generalist grazers (e.g., fishes and urchins) that can rapidly consume entire plants, several authors have concluded that seaweeds in areas impacted by these herbivores need to be adequately defended at all times and, thus, tend to have constitutive, rather than inducible, defenses (Paul and Van Alstyne 1988, Paul 1992, Steinberg 1992, 1994). Additionally, physical stresses alone, such as desiccation and UV exposure, can result in intraspecific differences in algal resistance to herbivores (Renaud et al. 1990, Cronin and Hay 1996b).

Given that both physical and biological factors can affect seaweed susceptibility to herbivores, and that we did not investigate these factors in our study, we decline to speculate on causes for most of the intraspecific differences we found (Fig. 3). In the case of Dictyota menstrualis from North Carolina (Fig. 1B, C), however, we provide a reasonable hypothesis that the striking difference in palatability between offshore and inshore populations could be driven by environmental differences, including herbivory and factors influencing algal productivity ("productivity potential" sensu Steneck and Dethier 1994; see also Bryant et al. 1983, Herms and Mattson 1992). Observations of algal morphology show that plants from our offshore site typically have numerous proliferating growths along blade margins, suggestive of amphipod grazing damage, whereas inshore plants have intact blades, indicating little, if any, amphipod grazing. Herbivore damage may be extremely costly for offshore algae due to turbid, low light conditions, necessitating stronger defenses (see Bryant et al. 1983, Coley et al. 1985, Tuomi 1992, Steneck and Dethier 1994). Dictyota menstrualis, which exhibited strong among-site differences in palatability, has recently been shown to induce increased levels of chemical defenses in response to amphipod grazing (Cronin and Hay 1996a). Although the mechanisms generating between-population differences in our study were not investigated, it is clear that large intraspecific differences in algal resistance to herbivory can occur over relatively short distances.

Few experiments have focused on testing hypotheses about temperate-tropical patterns in seaweed defenses. Several previous studies attempted to compare polyphenolics (a water-soluble class of algal compounds) in temperate and tropical brown algae (Steinberg 1989, Steinberg et al. 1991, Van Alstyne and Paul 1990), because polyphenolic production was thought to be higher in temperate than in tropical brown algae (in contrast to the general patterns we found for lipophilic chemical defenses). This apparent pattern was initially interpreted as the result of phlorotannins being ineffective defenses against tropical herbivorous fishes, but data on this hypothesis are contradictory. Steinberg et al. (1991) reported that reef fish in Australia did not discriminate between algae of high-phenolic (temperate Sargassum) and low-phenolic (tropical Sargassum) content. There were, however, measurable, stress-induced changes in levels of polyphenolics during transport and handling of the live plants prior to the assays, with unknown consequences. In contrast, Van Alstyne and Paul (1990) found that tropical reef fishes were deterred from feeding by phenolic-rich extracts from temperate brown algae, but not by phenolic-poor extracts from tropical brown algae. However, susceptibility of the temperate vs. tropical plants (as opposed to extracts) was not tested. The possibilities that nonpolar chemical defenses were stronger in tropical than in temperate algae, or that the algae differed in nutritive value, were not evaluated. Additionally, recent work in the Caribbean has shown that tropical brown seaweeds can be rich in phenolics (Targett et al. 1992), without apparent effect on herbivore digestive efficiency (Targett et al. 1995). Thus, there is little evidence that phlorotannins consistently function as defenses against tropical herbivores (or even temperate 
ones; Steinberg and van Altena 1992). Expectations for the role of phlorotannins in defending temperate vs. tropical algae are unclear.

In addition to the geographic patterns we demonstrated, Gaines and Lubchenco (1982) hypothesized that herbivory in the tropics has also affected the evolution of both algal size and morphology. Similarly, Steneck (1986) used paleontological data and morphological characteristics of encrusting coralline algae to argue that tropical herbivores have acted as strong selective agents shaping the evolution of corallines, with the result that algal forms resistant to herbivores are now more dominant in tropical than in temperate habitats.

Terrestrial as well as marine ecologists have hypothesized that a latitudinal gradient in plant defense has evolved in response to differential grazing pressure. For example, early investigators reported that alkaloid production was more common in tropical than in temperate plants (Levin 1976) and claimed that alkaloids from tropical plants were more toxic to plant enemies than alkaloids from temperate plants (Levin and York 1978). However, toxicity to ecologically relevant herbivores was not directly tested. Instead, toxicity was inferred from chemical structures, using a general structure-toxicity relationship based on pharmacological studies. Unfortunately, recent investigations indicate that neither pharmacological data nor assumed structure-function relationships are reliable predictors of toxicity or deterrency to ecologically relevant herbivores (Hay and Fenical 1988, Bernays 1991, Bryant et al. 1991, Bernays and Cornelius 1992, Hay and Steinberg 1992). As a second example, extrafloral nectaries of plants attract ants that protect them from insect herbivores (Janzen 1966, reviewed by Bentley 1977). Plants with extrafloral nectaries are more diverse and abundant in the tropics, suggesting a greater need for defense there. More recently, research in terrestrial systems has shown that insects consume greater amounts of leaf area in tropical broad-leaved forests than in temperate forests, and that plants in tropical habitats tend to be tougher and to contain more condensed tannins and crude fiber than plants in temperate habitats (Coley and Aide 1990).

All of these patterns are consistent with the hypothesis that herbivory is greater in the tropics and has selected for increases in plant defenses; however, alternative hypotheses remain. For example, although a large percentage of tropical plants produce allegedly toxic alkaloids, temperate plants may produce different classes of compounds that are equally deterrent to herbivores. Additionally, insects may consume greater amounts of foliage in tropical than in temperate zones because tropical plants are actually less defended and, thus, more palatable than temperate plants. Experiments offering terrestrial herbivores choices of temperate vs. tropical plants would be interesting.

In both terrestrial and marine systems, studies cor- relating large-scale within-latitude patterns of herbivory with plant defenses give additional support to the hypothesis that between-latitude differences in herbivory could have selected for stronger plant defenses in the tropics. In Australia, for example, the historical absence of large, tree-browsing herbivores is associated with the absence of extrafloral nectaries among many Acacia species (a genus typically possessing extrafloral nectaries), indicating a link on a geographic scale between the level and type of grazing pressure and the level of plant defense (Brown 1960). Additionally, a long history of intense herbivory by urchins and other grazers in temperate Australia appears to have selected for increased chemical defenses (i.e., elevated concentrations of polyphenolics and greater occurrence of nonpolar secondary metabolites) in Australian as opposed to North American brown algae (Estes and Steinberg 1988, Steinberg and van Altena 1992, Steinberg et al. 1995). Thus, although other environmental factors must be considered (Bryant et al. 1983, Coley et al. 1985, Herms and Mattson 1992), it appears that greater herbivory in tropical vs. temperate systems has resulted in defensive traits being more common or more highly developed among tropical plants in both marine and terrestrial systems.

In conclusion, despite local intraspecific variability such as that seen in Dictyota menstrualis, a large-scale geographic trend in palatability is apparent between seaweeds from temperate North Carolina waters and seaweeds from the tropical Bahamas. This is partially explained by lipophilic algal chemistry, and supports the hypothesis that tropical algae have developed stronger chemical defenses to withstand higher levels of grazing by tropical herbivores. However, some of the differences in herbivore resistance were not explained adequately by the algal secondary chemistry that we tested, stressing the need to consider palatability as the whole of many plant characteristics acting in concert. Finally, we caution against broadly generalizing this apparent latitudinal pattern before further investigations of seaweed palatability and chemical defenses are conducted in geographic regions beyond the two areas we sampled.

\section{ACKNOWLEDGMENTS}

Funding for this project was provided by NSF grants OCE 92-02847 and 95-29784 to M. E. Hay. Ship time in the Bahamas was provided by NSF grant CHE 90-08621 to William Fenical. Algal collections from offshore North Carolina were facilitated by NOAA/NURC grant UNCW 9308. We thank Niels Lindquist for helping to interpret our TLC plates, Suzanne Fredericq for identifying our algal specimens, Brian Chanas for help in measuring protein contents, Greg Cronin for advice on assays of chemical extracts, and Margaret Miller for help in collecting seaweeds and urchins in North Carolina. Comments from Joseph Pawlik, Niels Lindquist, Mike Klompas, and Mike Deal improved the manuscript.

\section{Literature Cited}

Bakus, G. J., and G. Green. 1974. Toxicity in sponges and holothurians: a geographic pattern. Science 185:951-953. 
Baldwin, I. T. 1990. Herbivory simulation in ecological research. Trends in Ecology and Evolution 5:91-93.

Bentley, B. L. 1977. Extrafloral nectaries and protection by pugnacious bodyguards. Annual Review of Ecology and Systematics 8:407-427.

Berenbaum, M., and J. J. Neal. 1985. Synergisms between myristicin and xanthotoxin, a naturally co-occurring plant toxicant. Journal of Chemical Ecology 11:1349-1358.

Bernays, E. A. 1991. Relationship between deterrence and toxicity of plant secondary compounds for the grasshopper Schistocerca americana. Journal of Chemical Ecology 17: 2519-2526.

Bernays, E. A., and M. Cornelius. 1992. Relationship between deterrence and toxicity of plant secondary compounds for the alfalfa weevil Hypera brunneipennis. Entomologia Experimentalis et Applicata 64:289-292.

Bertness, M. D., S. D. Garrity, and S. C. Levings. 1981. Predation pressure and gastropod foraging: a tropical-temperate comparison. Evolution 35:995-1007.

Bradford, M. M. 1976. A rapid and sensitive method for the quantitation of microgram quantities of protein utilizing the principle of protein-dye binding. Analytical Biochemistry 72:248-254.

Brown, W. L., Jr. 1960. Ants, acacias, and browsing mammals. Ecology 41:587-592.

Bryant, J. P., F. S. Chapin, III, and D. R. Klein. 1983. Carbon/nutrient balance of boreal plants in relation to vertebrate herbivory. Oikos 40:357-368.

Bryant, J. P., F. D. Provenza, J. Pastor, P. B. Reichardt, T. P. Clausen, and J. T. du Toit. 1991. Interactions between woody plants and browsing mammals mediated by secondary metabolites. Annual Review of Ecology and Systematics 22:431-446.

Carpenter, R. C. 1986. Partitioning herbivory and its effects on coral reef algal communities. Ecological Monographs 56:345-365.

Choat, J. H. 1982. Fish feeding and the structure of benthic communities in temperate waters. Annual Review of Ecology and Systematics 13:423-449.

Coen, L. D., and C. E. Tanner. 1989. Morphological variation and differential susceptibility to herbivory in the tropical brown alga Lobophora variegata. Marine Ecology Progress Series 54:287-298.

Coley, P. D., and T. M. Aide. 1990. Comparison of herbivory and plant defenses in temperate and tropical broad-leaved forests. Pages 25-49 in P. W. Price, T. M. Lewinsotin, G. W. Fernandes, and W. W. Benson, editors. Plant-animal interactions: evolutionary ecology in tropical and temperate regions. Wiley, New York, New York, USA.

Coley, P. D., J. P. Bryant, and F. S. Chapin, III. 1985. Resource availability and plant antiherbivore defense. Science 230:895-899.

Cronin, G., and M. E. Hay. 1996a. Induction of seaweed chemical defenses by amphipod grazing. Ecology 77:22872301.

Cronin, G., and M. E. Hay. 1996b. Susceptibility to herbivores depends on recent history of both the plant and animal. Ecology 77:1520-1532.

Cronin, G., N. Lindquist, M. E. Hay, and W. Fenical. 1995. Effects of storage and extraction procedures on yields of lipophilic metabolites from the brown seaweeds Dictyota ciliolata and Dictyota menstrualis. Marine Ecology Progress Series 119:265-273.

Duffy, J. E., and M. E. Hay. 1990. Seaweed adaptations to herbivory. Bioscience 40:368-375.

Duffy, J. E., and M. E. Hay. 1994. Herbivore resistance to seaweed chemical defense: the roles of mobility and predation risk. Ecology 75:1304-1319.

Duffy, J. E., and V. J. Paul. 1992. Prey nutritional quality and the effectiveness of chemical defenses against tropical reef fishes. Oecologia 90:333-339.

Estes, J. A., and P. D. Steinberg. 1988. Predation, herbivory, and kelp evolution. Paleobiology 14:19-36.

Faulkner, D. J. 1984. Marine natural products: metabolites of marine algae and herbivorous marine molluscs. Natural Product Reports 1:251-280.

- 1986. Marine natural products. Natural Product Reports $3: 2-33$.

. 1987. Marine natural products. Natural Product Reports 4:539-576.

P. 1988. Marine natural products. Natural Product Reports 5:613-663.

Po 1993. Marine natural products. Natural Product Reports 10:497-539.

Fenical, W. 1980. Distributional and taxonomic features of toxin-producing marine algae. Pages 144-151 in I. A. Abbott, M. S. Foster, and L. F. Eklund, editors. Pacific seaweed aquaculture. California Sea Grant College Program, Institute of Marine Resources, University of California, La Jolla, California, USA.

Gaines, S. D., and J. Lubchenco. 1982. A unified approach to marine plant-herbivore interactions. II. Biogeography. Annual Review of Ecology and Systematics 13:111-138.

Harvell, C. D. 1990. The ecology and evolution of inducible defenses. Quarterly Review of Biology 65:323-340.

Hatcher, B. G., and A. W. D. Larkum. 1983. An experimental analysis of factors controlling the standing crop of the epilithic algal community on a coral reef. Journal of Experimental Marine Biology and Ecology 69:61-84.

Hay, M. E. 1981. Herbivory, algal distribution, and the maintenance of between-habitat diversity on a tropical fringing reef. American Naturalist 118:520-540.

1984. Predictable spatial escapes from herbivory: how do these affect the evolution of herbivore resistance in tropical marine communities? Oecologia 64:396-407.

- 1985. Spatial patterns of herbivore impact and their importance in maintaining algal species richness. Proceedings of the Fifth International Coral Reef Congress 4:2934 .

2. 1986. Associational plant defenses and the maintenance of species diversity: turning competitors into accomplices. American Naturalist 128:617-641.

- 1991. Fish-seaweed interactions on coral reefs: effects of herbivorous fishes and adaptations of their prey. Pages 96-119 in P. F. Sale, editor. The ecology of fishes on coral reefs. Academic Press, San Diego, California, USA.

Hay, M. E., T. Colburn, and D. Downing. 1983. Spatial and temporal patterns in herbivory on a Caribbean fringing reef: the effects on plant distribution. Oecologia 58:299-308.

Hay, M. E., J. E. Duffy, and W. Fenical. 1988a. Seaweed chemical defenses: among-compound and among-herbivore variance. Proceedings of the Sixth International Coral Reef Symposium 3:43-48.

Hay, M. E., J. E. Duffy, and W. Fenical. 1990. Host plant specialization decreases predation on a marine amphipod: an herbivore in plant's clothing. Ecology 71:733-743.

Hay, M. E., J. E. Duffy, W. Fenical, and K. Gustafson. $1988 b$. Chemical defense in the seaweed Dictyopteris delicatula: differential effects against reef fishes and amphipods. Marine Ecology Progress Series 48:185-192.

Hay, M. E., J. E. Duffy, C. A. Pfister, and W. Fenical. $1987 a$. Chemical defense against different marine herbivores: are amphipods insect equivalents? Ecology 68:1567-1580.

Hay, M. E., and W. Fenical. 1988. Marine plant-herbivore interactions: the ecology of chemical defense. Annual Review of Ecology and Systematics 19:111-145.

Hay, M. E., W. Fenical, and K. Gustafson. 1987b. Chemical 
defense against diverse coral reef herbivores. Ecology $\mathbf{6 8}$ : 1581-1591.

Hay, M. E., Q. Kappel, and W. Fenical. 1994. Synergisms in plant defenses against herbivores: interactions of chemical defenses, calcification, and plant quality. Ecology 75: 1714-1726.

Hay, M. E., R. R. Lee, Jr., R. A. Guieb, and M. M. Bennett. 1986. Food preference and chemotaxis in the sea urchin Arbacia punctulata (Lamarck) Philippi. Journal of Experimental Marine Biology and Ecology 96:147-153.

Hay, M. E., and P. D. Steinberg. 1992. The chemical ecology of plant-herbivore interactions in marine vs. terrestrial communities. Pages 371-413 in G. Rosenthal and M. Berenbaum, editors. Herbivores: their interaction with secondary plant metabolites. Second edition, Volume II. Evolutionary and ecological processes. Academic Press, San Diego, California, USA.

Heck, K. L., Jr., and K. A. Wilson. 1987. Predation rates on decapod crustaceans in latitudinally separated seagrass communities: a study of spatial and temporal variation using tethering techniques. Journal of Experimental Marine Biology and Ecology 107:87-100.

Herms, D. A., and W. J. Mattson. 1992. The dilemma of plants: to grow or to defend? Quarterly Review of Biology 67:283-335.

Horn, M. H. 1989. Biology of marine herbivorous fishes. Oceanography and Marine Biology Annual Review 27: $167-272$

Horn, M. H., and M. A. Neighbors. 1984. Protein and nitrogen assimilation as a factor in predicting the seasonal macroalgal diet of the monkeyface prickleback. Transactions of the American Fisheries Society 113:388-396.

Janzen, D. H. 1966. Coevolution of mutualism between ants and acacias in Central America. Evolution 20:249-275.

Jeanne, R. L. 1979. A latitudinal gradient in rates of ant predation. Ecology 60:1211-1224.

Lawrence, J. M. 1975. On the relationships between marine plants and sea urchins (Echinodermata: Echinoidea). Oceanography and Marine Biology Annual Review 13: 213-286.

Lessios, H. A. 1988. Mass mortality of Diadema antillarum in the Caribbean: what have we learned? Annual Review of Ecology and Systematics 19:371-393.

Levin, D. A. 1976. The chemical defenses of plants to pathogens and herbivores. Annual Review of Ecology and Systematics 7:121-159.

Levin, D. A., and B. M. York. 1978. The toxicity of plant alkaloids: an ecogeographic perspective. Biochemical Systematics and Ecology 6:61-76.

Lewis, S. M. 1986. The role of herbivorous fishes in the organization of a Caribbean reef community. Ecological Monographs 56:183-200.

Lewis, S. M., J. N. Norris, and R. B. Searles. 1987. The regulation of morphological plasticity in tropical reef algae by herbivory. Ecology 68:636-641.

Littler, D. S., and M. M. Littler. 1990. Systematics of Udotea species (Bryopsidales, Chlorophyta) in the tropical western Atlantic. Phycologia 29:206-252.

Littler, M. M., P. R. Taylor, and D. S. Littler. 1986. Plant defense associations in the marine environment. Coral Reefs 5:63-71.

Mattson, W. J., Jr. 1980. Herbivory in relation to plant nitrogen content. Annual Review of Ecology and Systematics 11:119-161.

Menge, B. A., and J. Lubchenco. 1981. Community organization in temperate and tropical rocky intertidal habitats: prey refuges in relation to consumer pressure gradients. Ecological Monographs 51:429-450.

Miller, M., and M. E. Hay. 1996. Coral-seaweed-grazer- nutrient interactions on temperate reefs. Ecological Monographs 66:323-344.

Morrison, D. E. 1988. Comparing fish and urchin grazing in shallow and deeper coral reef algal communities. Ecology 69:1367-1382.

Neighbors, M. A., and M. H. Horn. 1991. Nutritional quality of macrophytes eaten and not eaten by two temperate-zone herbivorous fishes: a multivariate comparison. Marine Biology 108:471-476.

Norris, J. N., and W. Fenical. 1982. Chemical defense in tropical marine algae. Pages 417-431 in K. Rutzler and I. G. Macintyre, editors. The Atlantic barrier reef ecosystem at Carrie Bow Cay, Belize. I. Structure and communities. Smithsonian Contributions to the Marine Sciences, Volume 12.

Paul, V. J. 1987. Feeding deterrent effects of algal natural products. Bulletin of Marine Science 41:514-522.

- editor. 1992. Ecological roles of marine natural products. Comstock Press, Ithaca, New York, USA.

Paul, V. J., and W. Fenical. 1986. Chemical defense in tropical green algae, order Caulerpales. Marine Ecology Progress Series 34:157-169.

Paul, V. J., and M. E. Hay. 1986. Seaweed susceptibility to herbivory: chemical and morphological correlates. Marine Ecology Progress Series 33:255-264.

Paul, V. J., and K. L. Van Alstyne. 1988. Chemical defense and chemical variation in some tropical Pacific species of Halimeda (Halimedaceae; Chlorophyta). Coral Reefs 6: 263-269.

Paul, V. J., and K. L. Van Alstyne. 1992. Activation of chemical defenses in the tropical green algae Halimeda spp. Journal of Experimental Marine Biology and Ecology 160: 191-203.

Paul, V. J., C. R. Wylie, and H. R. Sanger. 1988. Effects of algal chemical defenses toward different coral-reef herbivorous fishes. Proceedings of the Sixth International Coral Reef Symposium 3:73-78.

Renaud, P. E., M. E. Hay, and T. M. Schmitt. 1990. Interactions of plant stress and herbivory: intraspecific variation in the susceptibility of a palatable vs. an unpalatable seaweed to sea urchin grazing. Oecologia 82:217-226.

Rice, W. R., and S. D. Gaines. 1994. "Heads I win, tails you lose": testing directional alternative hypotheses in ecological and evolutionary research. Trends in Ecology and Evolution 9:235-237.

Schiel, D. R., and M. S. Foster. 1986. The structure of subtidal algal stands in temperate waters. Oceanography and Marine Biology Annual Review 24:265-307.

Schmitt, T. M., M. E. Hay, and N. Lindquist. 1995. Constraints on chemically mediated coevolution: multiple functions of seaweed secondary metabolites. Ecology 76:107123

Steinberg, P. D. 1985. Feeding preferences of Tegula funebralis and chemical defenses of marine brown algae. Ecological Monographs 55:333-349.

1988. Effects of quantitative and qualitative variation in phenolic compounds on feeding in three species of marine invertebrate herbivores. Journal of Experimental Marine Biology and Ecology 120:221-237.

989. Biogeographical variation in brown algal polyphenolics and other secondary metabolites: comparison between temperate Australasia and North America. Oecologia 78:373-382.

1992. Geographical variation in the interaction between marine herbivores and brown algal secondary metabolites. Pages 51-92 in V. J. Paul, editor. Ecological roles of marine natural products. Comstock Press, Ithaca, New York, USA.

1994. Lack of short-term induction of phlorotannins in the Australian brown algae Ecklonia radiata and Sar- 
gassum vestitum. Marine Ecology Progress Series 112:129133.

1995. Interaction between the canopy dwelling echinoid Holopneustes purpurescens and its host kelp Ecklonia radiata. Marine Ecology Progress Series 127:169-181.

Steinberg, P. D., K. Edyvane, R. de Nys, R. Birdsey, and I. A. van Altena. 1991. Lack of avoidance of phenolic-rich brown algae by tropical herbivorous fishes. Marine Biology 109:335-343.

Steinberg, P. D., J. A. Estes, and F. C. Winter. 1995. Evolutionary consequences of food chain length in kelp forest communities. Proceedings of the National Academy of Sciences (USA) 92:8145-8148.

Steinberg, P. D., and V. J. Paul. 1990. Fish feeding and chemical defenses of tropical brown algae in Western Australia. Marine Ecology Progress Series 58:253-259.

Steinberg, P. D., and I. van Altena. 1992. Tolerance of marine invertebrate herbivores to brown algal phlorotannins in temperate Australasia. Ecological Monographs 62:189222.

Steneck, R. S. 1986. The ecology of coralline algal crusts: convergent patterns and adaptive strategies. Annual Review of Ecology and Systematics 17:273-303.

Steneck, R. S., and W. H. Adey. 1976. The role of environment in control of morphology in Lithophyllum congestum, a Caribbean algal ridge builder. Botanica Marina 19:197215.

Steneck, R. S., and M. N. Dethier. 1994. A functional group approach to the structure of algal-dominated communities. Oikos 69:476-498.

Targett, N. M., A. A. Boettcher, T. E. Targett, and N. H.
Vrolijk. 1995. Tropical marine herbivore assimilation of phenolic-rich plants. Oecologia 103:170-179.

Targett, N. M., L. D. Coen, A. A. Boettcher, and C. E. Tanner. 1992. Biogeographic comparisons of marine algal polyphenolics: evidence against a latitudinal trend. Oecologia 89:464-470.

Targett, N. M., and O. J. McConnell. 1982. Detection of secondary metabolites in marine algae using the marsh periwinkle, Littorina irrorata Say, as an indicator organism. Journal of Chemical Ecology 8:115-125.

Tuomi, J. 1992. Toward integration of plant defense theories. Trends in Ecology and Evolution 7:365-367.

Vadas, R. L. 1977. Preferential feeding: an optimization strategy in sea urchins. Ecological Monographs 47:337371.

Van Alstyne, K. L. 1988. Herbivore grazing increases polyphenolic defenses in the intertidal brown alga Fucus distichus. Ecology 69:655-663.

Van Alstyne, K. L., and V. J. Paul. 1990. The biogeography of polyphenolic compounds in marine macroalgae: temperate brown algal defenses deter feeding by tropical herbivorous fishes. Oecologia 84:158-163.

Vermeij, G. J. 1978. Biogeography and adaptation. Harvard University Press, Cambridge, Massachusetts, USA.

Wylie, C. R., and V. J. Paul. 1988. Feeding preferences of the surgeonfish Zebrasoma flavescens in relation to chemical defenses of tropical algae. Marine Ecology Progress Series 45:23-32.

Yates, J. L., and P. Peckol. 1993. Effects of nutrient availability and herbivory on polyphenolics in the seaweed $\mathrm{Fu}$ cus vesiculosus. Ecology 74:1757-1766.

\section{APPENDIX}

Udotea cyathiformis (Bahamas and North Carolina). The genus Udotea produces bioactive but unstable sesquiterpenes and diterpenes (Faulkner 1986), two of which, udoteal and flexilin, can deter feeding by herbivorous reef fishes in the Pacific (Paul 1987, Paul et al. 1988). Flexilin and a related sesquiterpene from $U$. cyathiformis significantly deter feeding by fishes, an urchin, and an amphipod from the Caribbean (Hay et al. 1994). Our TLCs of fresh plant extracts from Crooked Island, Bahamas show several nonpolar UV-active spots $\left(R_{\mathrm{f}}=0.38-0.54,1: 1\right.$ hexane : ether $)$ that do not appear in TLCs of samples of freeze-dried material, indicating some breakdown of algal metabolites for this collection.

$U$. dixonii, prev. flabellum (Bahamas). TLCs show the presence of a UV-active spot $\left(R_{\mathrm{f}}=0.5,1: 1\right.$ hexane : ether $)$. No major differences were apparent between fresh and freezedried samples. Udoteal, the major metabolite of freshly extracted $U$. flabellum, is unstable. Udoteafuran, a minor product, and a complex mixture of the hydrates of udoteatrial were found in ethanol-preserved $U$. flabellum (Faulkner 1984). A collection of $U$. flabellum from the Bahamas contained two dialdehydes, including petiodial, which had earlier been isolated from Mediterranean U. petiolata (Faulkner 1986, Paul and Fenical 1986)

$U$. looensis, prev. cyathiformis (Bahamas). TLCs show the presence of a nonpolar UV-active spot $\left(R_{\mathrm{f}}=0.64,1: 1\right.$ hexane ether) similar to that of the UV-active spot in $U$. cyathiformis TLCs. No chemical investigations of this species have been published since its recent taxonomic separation from $U$. $c y$ athiformis (Littler and Littler 1990).

Lobophora variegata, "zonate decumbent-" and "brown decumbent-" bladed forms (Bahamas and North Carolina). TLCs show very few nonpolar metabolites, with several UV-active polar spots $\left(R_{\mathrm{f}}=0.13\right.$, baseline, ether $)$. TLCs of extracts of fresh and freeze-dried material were similar. Coen and Tanner (1989) suggested that $L$. variegata may possess secondary compounds that could explain differential herbivore resistance among the species' different morphs. Paul and Hay (1986) found this to be a low-preference alga for reef fishes in field assays, probably due to chemical defense. Caribbean populations contain very high levels of polyphenolics, which do not appear to affect local herbivores (Targett et al. 1992, 1995).

Amphiroa fragilissima (Bahamas). TLCs of extracts of fresh and freeze-dried algae reveal no major differences and show two purple-staining spots $\left(R_{\mathrm{f}}=0.68,0.93,19: 1\right.$ ether : $\mathrm{MeOH})$ and slight $\mathrm{UV}$ activity $\left(R_{\mathrm{f}}=0.39,0.86,19: 1\right.$ ether : $\mathrm{MeOH})$. Secondary chemistry of this genus is poorly known. In Belize, this species escapes fish grazing when it grows in association with the chemically defended Stypopodium zonale (Littler et al. 1986), suggesting that it is palatable to reef fishes.

A. beauvoisii (North Carolina). Few spots suggestive of unique secondary metabolites appear on TLC plates, whether extracts are from live plants or freeze-dried material.

Padina jamaicensis (Bahamas). For this collection, TLCs of fresh algal extract were not performed. TLCs of freezedried plant extract indicated polar UV activity of compound(s) on the baseline in 19:1 ether: $\mathrm{MeOH}$. This species is well-known for its morphological plasticity. It grows as an herbivore-resistant turf in heavily grazed areas, but rapidly switches to an upright, fan-shaped form when herbivores are removed (Lewis et al. 1987). Chemical defenses have not been documented, but other members of the genus appear to have some chemical defenses; specific compounds have not been identified (Renaud et al. 1990).

$P$. gymnospora (North Carolina). TLCs of extracts from fresh and freeze-dried algae were similar and show UV activity on the baseline in 19:1 ether: $\mathrm{MeOH}$. Previous work suggests this alga is chemically defended from herbivory ( $\mathrm{Re}-$ naud et al. 1990), but attempts to isolate the secondary chem- 
istry have been inconclusive (M. E. Hay, personal communication).

Dictyopteris justii (Bahamas). UV activity is apparent on and immediately above the baseline for TLCs (19:1 ether: methanol) of extracts from fresh and freeze-dried material. This genus is known to produce aromatic hydrocarbon rings as well as terpenes (Hay and Fenical 1988). Dictyopterenes A and B from Caribbean D. delicatula have deterred herbivorous reef fishes but not amphipods (Hay et al. 1988b).

D. hoytii (North Carolina). Except for some UV activity at the baseline (19:1 ether: $\mathrm{MeOH})$, we did not observe any spots suggestive of prominent secondary metabolites in our TLCs, using extracts of fresh and freeze-dried plants.

Sargassum hystrix (Bahamas). TLCs show a UV-active spot at $R_{\mathrm{f}}=0.5$ and at the baseline (19:1 ether: methanol), but otherwise little in the way of secondary chemistry. No major differences in TLCs were apparent between extracts of fresh and freeze-dried seaweed.

S. polyceratium (Bahamas). Very little interesting secondary chemistry was revealed by our TLCs for this collection. We could find no major changes between TLCs of extracts of fresh and freeze-dried algae.

S. filipendula (North Carolina). TLCs using extracts of fresh and freeze-dried material revealed slight UV activity on the baseline (19:1 ether: $\mathrm{MeOH})$, but no obvious spots indicating unique secondary metabolites.

Dictyota pulchella, prev. divaricata (Bahamas). The genus Dictyota is well-known to produce a diversity of secondary metabolites, mostly terpenoid compounds (Faulkner 1984, $1986,1987,1988,1993)$, many of which have been shown to deter herbivores in laboratory and field studies (reviewed by Hay 1991, Hay and Steinberg 1992; updated by Duffy and Hay 1994, Cronin and Hay 1996a). Many new diterpenes recently have been isolated from the species $D$. divaricata (Faulkner 1993). Our TLCs of extracts (from fresh and freezedried plants) of $D$. pulchella showed numerous UV-active spots in the nonpolar region (reddish brown-staining spots at $R_{\mathrm{f}}=0.26$ and 0.32 , and nonstaining spots at $R_{\mathrm{f}}=0.5$ and $0.68,1: 1$ ether: hexanes). Collections from separate sites in the Bahamas exhibited differences; e.g., TLCs of extracts from a mangrove channel collection showed two purple-staining spots $\left(R_{\mathrm{f}}=0.56,0.42\right.$ [UV], $1: 1$ ether $:$ hexanes $)$ that were not evident in TLCs of samples from a deep reef wall collection.

D. bartayresiana, prev. bartayresii (Bahamas). The major metabolite of this species is pachydictyol A (Norris and Fenical 1982), a documented feeding deterrent to macroherbivores and some mesograzers (Hay 1991, Duffy and Hay 1994; but see Hay et al. 1990). Extract of $D$. bartayresiana in the Pacific deterred feeding by the surgeonfish Zebrasoma flavescens (Wylie and Paul 1988). Our TLCs of fresh and freezedried algae showed UV activity at $R_{\mathrm{f}}=0.65$ (ether), although a distinct spot suggestive of pachydictyol A was not obvious.

D. cervicornis (Bahamas). TLCs showed the presense of a purple-staining UV spot $\left(R_{\mathrm{f}}=0.26,1: 1\right.$ ether $:$ hexanes $)$ and several UV-active spots $\left(R_{\mathrm{f}}=0.13,0.39,1: 1\right.$ ether : hexanes $)$. No major changes in TLCs were noted between fresh and freeze-dried algal samples. Chemical defenses have been proposed to explain the resistance to herbivory of $D$. cervicornis in field assays (Littler et al. 1986, Paul and Hay 1986). Cervicol, a secodolastane, is a metabolite of this species (Faulkner 1987), as are other dolastane-type and secodolastane-type diterpenes, including isolinearol and isolinearol acetate (Faulkner 1988). Dictyol B acetate was isolated from D. cervicornis at $0.04 \%$ dry mass, but the compound did not affect the behavior of the gastropod Littorina sp. (Targett and McConnell 1982). However, dictyol B acetate has been shown to deter a temperate urchin, fish, and amphipod (Cronin and Hay 1996b), as well as tropical reef fishes (Hay et al. 1990).

D. caribea, prev. indica (Bahamas). Our TLCs do not indicate major changes between extracts of fresh and freezedried material, and show several spots indicative of secondary metabolites (reddish brown-staining, UV-active spot at $R_{\mathrm{f}}=$ 0.85 , ether; purple-staining spot at $R_{\mathrm{f}}=0.39$, two pink-staining spots at $R_{\mathrm{f}}=0.61$ and $0.71,1: 1$ ether: hexanes). Compounds isolated from the seaweed $D$. indica include two C-14 epimers: dictyotriol A and dictyotriol B (Faulkner 1986), and diterpenes: amijol, dictinol, dictindiol, and dictintriol (Faulkner 1993). Investigations into possible antiherbivore functions of these metabolites have not been published.

$D$. mertensii, prev. dentata (Bahamas). A UV-active spot $\left(R_{\mathrm{f}}=0.70,19: 1\right.$ ether $\left.: \mathrm{MeOH}\right)$ and a purple-staining spot $\left(R_{\mathrm{f}}\right.$ $=0.6,19: 1$ ether $: \mathrm{MeOH})$ are present on TLC plates of both fresh and freeze-dried samples. Dictyol $\mathrm{H}$ is a known metabolite of $D$. dentata from Barbados (Faulkner 1986). It significantly deters feeding by herbivorous reef fish (Hay et al. $1988 a$ ).

D. alternans, prev. Dilophus alternans (Bahamas). TLCs of both fresh and freeze-dried tissue show strong UV activity at $R_{\mathrm{f}}=0.68$. Nothing has been published on chemistry of this species, but it was a low-preference alga for reef fishes in the Florida Keys and may possess chemical defenses (Paul and Hay 1986).

D. menstrualis, prev. dichotoma (North Carolina). Major metabolites of this species are the diterpene alcohols dictyol E and pachydictyol A, which deter feeding by fish, urchins, and some amphipods (reviewed by Hay and Steinberg 1992; updated by Duffy and Hay 1994, Cronin and Hay 1996a, $b$ ). Although TLCs provide only the crudest measure of quantitative data, our TLCs suggested that $D$. menstrualis from offshore North Carolina contained greater concentrations of these two compounds than did plants from inshore North Carolina (G. Cronin, personal communication). Cronin et al. (1995) showed that dictyol E and pachydictyol A were stable, but dictyodial, another metabolite of both $D$. menstrualis and D. ciliolata, decomposed during freeze-drying or extended storage.

D. ciliolata (North Carolina). The major metabolites of $D$. ciliolata are dictyol B acetate and pachydictyol A (Cronin et al. 1995). Dictyol B acetate deters feeding by Caribbean reef fishes (Hay et al. 1990), as well as temperate fishes, urchins, and some amphipods (Duffy and Hay 1994, Cronin and Hay $1996 a, b)$. Our TLCs do not show appreciable changes between samples of fresh and freeze-dried plants. 